\title{
Effects of aerosol-radiation interaction on precipitation during biomass-burning season in East China
}

\author{
Xin Huang ${ }^{1,2,3}$, Aijun Ding ${ }^{1,2,3}$, Lixia Liu ${ }^{1,2}$, Qiang Liu ${ }^{1,2}$, Ke Ding ${ }^{1,2}$, Xiaorui Niu ${ }^{1,2,3}$, Wei Nie ${ }^{1,2,3}$, Zheng Xu ${ }^{1,2,3}$, \\ Xuguang Chi ${ }^{1,2,3}$, Minghuai Wang ${ }^{1,2,3}$, Jianning Sun ${ }^{1,2,3}$, Weidong Guo ${ }^{1,2,3}$, and Congbin Fu ${ }^{1,2,3}$ \\ ${ }^{1}$ Joint International Research Laboratory of Atmospheric and Earth System Sciences, Nanjing University, \\ Nanjing, China \\ ${ }^{2}$ Institute for Climate and Global Change Research \& School of Atmospheric Sciences, \\ Nanjing University, Nanjing, 210023, China \\ ${ }^{3}$ Collaborative Innovation Center of Climate Change, Jiangsu province, China \\ Correspondence to: Aijun Ding (dingaj@nju.edu.cn)
}

Received: 30 March 2016 - Published in Atmos. Chem. Phys. Discuss.: 6 April 2016

Revised: 15 July 2016 - Accepted: 19 July 2016 - Published: 9 August 2016

\begin{abstract}
Biomass burning is a main source for primary carbonaceous particles in the atmosphere and acts as a crucial factor that alters Earth's energy budget and balance. It is also an important factor influencing air quality, regional climate and sustainability in the domain of Pan-Eurasian Experiment (PEEX). During the exceptionally intense agricultural fire season in mid-June 2012, accompanied by rapidly deteriorating air quality, a series of meteorological anomalies was observed, including a large decline in near-surface air temperature, spatial shifts and changes in precipitation in Jiangsu province of East China. To explore the underlying processes that link air pollution to weather modification, we conducted a numerical study with parallel simulations using the fully coupled meteorology-chemistry model WRFChem with a high-resolution emission inventory for agricultural fires. Evaluation of the modeling results with available ground-based measurements and satellite retrievals showed that this model was able to reproduce the magnitude and spatial variations of fire-induced air pollution. During the biomass-burning event in mid-June 2012, intensive emission of absorbing aerosols trapped a considerable part of solar radiation in the atmosphere and reduced incident radiation reaching the surface on a regional scale, followed by lowered surface sensible and latent heat fluxes. The perturbed energy balance and re-allocation gave rise to substantial adjustments in vertical temperature stratification, namely surface cooling and upper-air heating. Furthermore, an intimate link between temperature profile and small-scale processes
\end{abstract}

like turbulent mixing and entrainment led to distinct changes in precipitation. On the one hand, by stabilizing the atmosphere below and reducing the surface flux, black carbonladen plumes tended to dissipate daytime cloud and suppress the convective precipitation over Nanjing. On the other hand, heating aloft increased upper-level convective activity and then favored convergence carrying in moist air, thereby enhancing the nocturnal precipitation in the downwind areas of the biomass-burning plumes.

\section{Introduction}

Biomass burning, defined as open or quasi-open combustion of non-fossilized vegetative or organic fuel, is widely used by humans to manage and transform land cover for many purposes and has been identified as one of the most important disturbance agents in world's terrestrial ecosystems (Fearnside, 2000). It is a major source of many trace gases and particulate matters on a regional and even a global scale (Andreae and Merlet, 2001; van der Werf et al., 2006; Ito et al., 2007), contributing significantly to the budgets of trace gases, greenhouse gases and atmospheric aerosols (Langenfelds et al., 2002). For instance, biomass burning is estimated to be responsible for almost half of global carbon monoxide $(\mathrm{CO})$ emission and more than one third of total black carbon (BC) emission (Bergamaschi et al., 2000; Bond et al., 2013). With tremendous and intensive emission of atmo- 
spheric pollutants, it has been recognized as one of the culprits of regional air pollution (Wiedinmyer et al., 2006; Ryu et al., 2007) and an important disturber of biogeochemical cycles, especially for those of carbon and nitrogen (Crutzen and Andreae, 1990; Kuhlbusch, 1998). In the Eurasian continent, i.e., the main domain of the Pan-Eurasian Experiment (PEEX) (Kulmala et al., 2015), biomass burning is a very important source influencing air quality, regional climate change and sustainability (Chi et al., 2013; Ding et al., 2013a, b; Lappalainen et al., 2016). In East China, the impact of biomass burning to air quality and regional climate change is particularly interesting because of the mixing of biomassburning plumes with pollutant from fossil fuel combustion sources (Ding et al., 2013a; Nie et al., 2015; Xie et al., 2015; Lappalainen et al., 2016).

Biomass burning, including forest fires, savanna fires, peat burning and crop residue burning in field, generally features a high emission rate of light-absorbing carbonaceous aerosols (Reid et al., 1998; Schwarz et al., 2008). The most important one is BC, which is intensively emitted during biomassburning events due to incomplete combustions (Reid et al., 2005; Akagi et al., 2011). As the dominant absorber of solar radiation in the atmosphere, BC warms the Earthatmospheric system and alters the partitioning of energy between the ground surface and the atmosphere, thereby modifying atmospheric thermodynamic structures and modulating hydrological cycles (Krishnan and Ramanathan, 2002; Ramanathan et al., 2005; Ding et al., 2016). These modifications induced by biomass burning have been detected in many regions, especially for those during forest fires. Surface temperature decline was extensively observed during forest fires in North America, Asia and Africa (Robock, 1988, 1991; Procopio et al., 2004; Kolusu et al., 2015). The dimming around ground surface and heating in the upper atmosphere, especially in the upper boundary layer, could cause the suppression of daytime mixing height and result in an enhancement of surface air pollution through aerosol-boundarylayer-radiation feedbacks (Ding et al., 2013a, 2016). This effect was named as the "dome effect" of BC by Ding et al. (2016). By cooling the surface and stabilizing the atmosphere, intense forest fires may lead to the inhibition of cloud formation (Andreae et al., 2004; Koren et al., 2004; Feingold et al., 2005), suppression in precipitation (Rosenfeld, 1999; Sakaeda et al., 2011) and even temporal shift in onset of monsoon (Liu et al., 2005; Lau et al., 2006; Zhang et al., 2009). In short, BC has been demonstrated to cause a significant perturbation in the radiative energy balance and has even led to regional and global climate change (Penner et al., 1992; Menon et al., 2002; Ramanathan and Carmichael, 2008).

Although forest and savanna fires are much less notable in China compared with tropical America, Africa and Southeast Asia (van der Werf et al., 2006), it is noteworthy that China is a large country with the world's top-ranked agricultural production, which is inevitably accompanied by a tremendous amount of crop residue. Field burning of crop residue is a common and widespread management practice in China during post-harvest periods for the purpose of clearing farmland and providing short-lived ash fertilization for the crop rotation (Gao et al., 2002). It is estimated that about $120 \mathrm{Tg}$ of crop residue is burned in fields across China every year, far higher than that burned in forest fires and savanna fires (Yan et al., 2006). Previous studies have documented that field burning of crop residue led to deterioration in regional air quality during harvest season (Yang et al., 2008; Huang et al., 2012b; Li et al., 2014). What is worse, this kind of pollution occurs periodically in East China, particularly during the harvest period of wheat in June (Fig. 1). However, studies regarding its effects on meteorology and climate are still limited. Ding et al. (2013a) reported that temperature and precipitation were dramatically modified during the harvest season in 2012 according to ground-based measurements at a regional background station SORPES in the Yangtze River Delta region in East China (Ding et al., 2013b). However, there is a lack of a comprehensive picture of how or through which processes the biomass-burning plumes influenced the air temperature and precipitation and on what scale the aerosol-weather interactions happened during this case.

Here we conducted numerical simulations for the biomassburning event in East China during mid-June 2012 based on the online coupled meteorology-chemistry model WRFChem (the Weather Research and Forecasting model coupled with Chemistry) combined with multiple ground-based measurements and remote-sensing retrievals. The rest of this paper is structured as follows: Sect. 2 describes the development of an emission inventory for field burning of crop residues and how the numerical simulations are configured and designed; in Sect. 3 we validate the modeling results using available measurements and then analyze the perturbations in energy budget and temperature adjustments induced by crop residue burning; finally, three regions with distinct precipitation changes, located near or downwind from the burning sites, are selected to be discussed in detail. Conclusions are drawn in Sect. 4.

\section{Data and methodology}

\subsection{Emission inventory}

Modeling aerosols' radiative effects during this biomassburning event first requires accurate quantification and meticulous characterization of emission from field burning of crop residue. Here, emission intensities of trace gases and particulate matters, specifically including carbon dioxide $\left(\mathrm{CO}_{2}\right)$, $\mathrm{CO}$, methane $\left(\mathrm{CH}_{4}\right)$, non-methane organic compounds (NMOCs), nitrogen oxides $\left(\mathrm{NO}_{x}\right)$, ammonia $\left(\mathrm{NH}_{3}\right)$, sulfur dioxide $\left(\mathrm{SO}_{2}\right), \mathrm{BC}$, organic carbon $(\mathrm{OC})$ and particulate matter $\left(\mathrm{PM}_{2.5}\right.$ and $\mathrm{PM}_{10}$ are particles with aerodynamic diameter less than 2.5 and 10 microns respectively), were estimated based on a bottom-up method. According to 
(a)

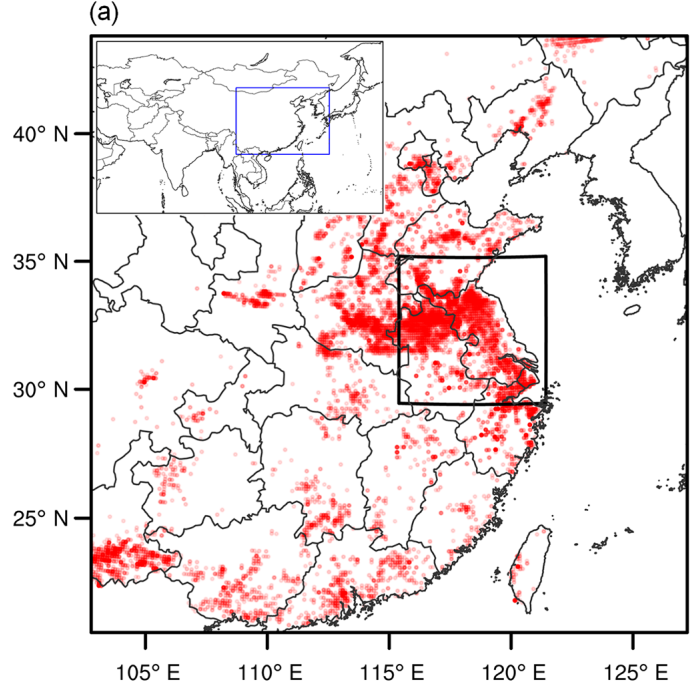

(b)

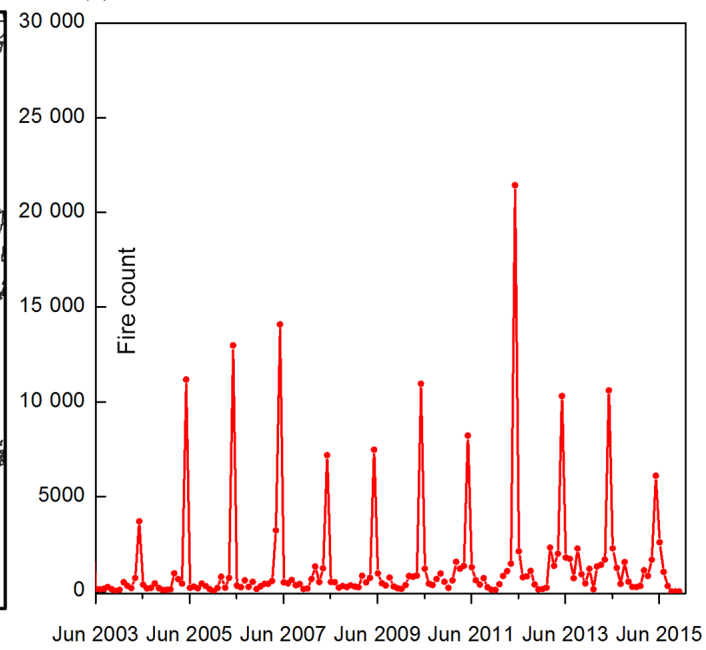

Figure 1. (a) Distribution of 13-year total fire detections by MOD14A1 during 2003-2015 in the WRF-Chem coarse domain. The black rectangle represents the inner domain. The top left corner gives a map showing the geographic location of the model domain. (b) Thirteenyear time series of monthly fire detections in the model coarse domain based on MOD14A1 retrievals.

the farming season (available at http://zzys.agri.gov.cn) and province-level statistics on crop cultivation (NBSC, 2013), we can deduce that the intensive agricultural fires in June were mainly related to wheat straw burning as a consequence of the extensively spreading cultivation mode of "winter wheat-summer corn/rice" in East China. Burned biomass at province-level was calculated based on statistical data of crop productions, residue-to-production ratios and percentages of crop residues burned in the field. Emissions of various pollutants were derived from the product of burned mass and experiment results on crop-specific combustion efficiencies and pollutant-specific emission factors. The detailed methods and involved datasets are described in our previous work (Huang et al., 2012b).

To determine the locations and time of crop residue fires, MODIS (Moderate Resolution Imaging Spectroradiometer, available at https://ladsweb.nascom.nasa.gov/data/) Thermal Anomalies/Fire Daily L3 Global product (MOD/MYD14A1) combined with burned area product (MCD45A1) were introduced for the purpose of emission spatiotemporal allocations (Giglio et al., 2003; Boschetti et al., 2009). MOD/MYD14A1 provides fire identification by examining the brightness temperature relative to neighboring pixels. MCD45A1 was also incorporated in this work because its bidirectional reflectance model-based change detection approach has been proved to be capable of presenting a more accurate mapping of smaller fragments of burn scars (Roy and Boschetti, 2009). The Global Land Cover (GLC) product with a spatial resolution of $1 \mathrm{~km}$ was used in this study to identify the burning of different biomass. Only fire detections that occurred on farmland, i.e., land cover classes defined as "farm" and "mosaic of cropping", were identified as field burning of crop residue.
Emission at province level estimated using the aforementioned method was then allocated equally to each fire spot.

The fire emission estimation developed in this work was compared with the FINN fire emission dataset. Spatially, these two emission inventories generally were consistent with each other because the locations for the fires in both inventories are based on MODIS Thermal Anomalies product (Fig. S1 in the Supplement). Some inconsistencies, such as the density of fire in central Jiangsu, are attributed to the different land cover dataset applied for the identification of underlying biomass type. FINN fire emission estimation used MODIS Collection 5 Land Cover Type data (Wiedinmyer et al., 2011), while we employed Global Land Cover data. This inventory differs slightly from FINN estimation in magnitude. Taking $\mathrm{CO}$ emission in the inner model domain for instance, we estimate that $4.5 \mathrm{Tg} \mathrm{CO}$ was emitted while FINN gives the value of $7.5 \mathrm{Tg}$ during the first half of June 2012. It might be attributed to different methods to estimate burned biomass. FINN used MODIS Vegetation Continuous Fields to assign the burned mass. The fuel loading of farmland was assumed to be $0.5 \mathrm{~kg} \mathrm{~m}^{-2}$ (Wiedinmyer et al., 2006). However, in China, crop straw is used in multiple ways that differ regionally, like biofuel, biogas production and animal feed supply, which is highly dependent on crop species. We estimated the emission using a "bottom-up" method by fully considering crop yields, crop-specific straw usage and combustion efficiency.

During this agricultural fire event, the spatial pattern of fire detections in Fig. 2a indicates that open burning of straw mostly concentrated in northern parts of Anhui and Jiangsu province and got extremely severe on 9 and 13 June, as displayed in Fig. 2b. Burning of crop residues dominated lo- 

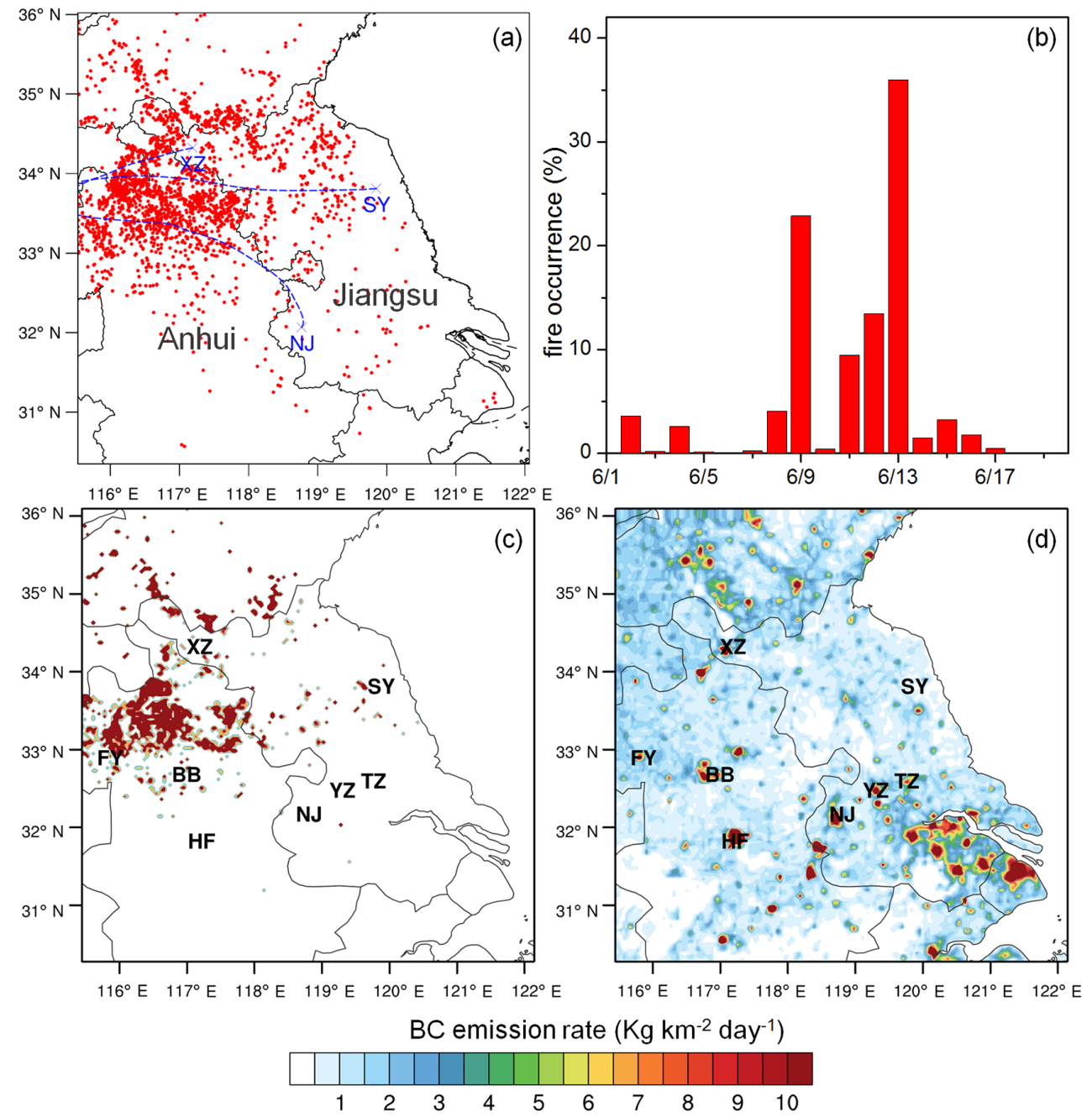

Figure 2. (a) Satellite fire detections in June 2012 and backward trajectories for NJ (Nanjing), XZ (Xuzhou) and SY (Sheyang). (b) Temporal variations of daily fire occurrences. BC emission rates from (c) agricultural fires and (d) anthropogenic activities on 9 June. Note that the backward trajectories were calculated for an altitude of $2 \mathrm{~km}$ over NJ, XZ and SY from 14:00 LT and 18:00 LT on 10 June and 01:00 LT on 11 June (Draxler and Rolph, 2003). Anhui and Jiangsu provinces are labeled in gray in Fig. 2a.

cal emissions of atmospheric pollutants when compared with corresponding anthropogenic emissions. Taking BC for instance (Fig. 2c and d), emission rate from field burning of crop residues far outweighed that from industry, power plant, residential activity and transportation combined ( $\mathrm{Li}$ et al., 2015).

\subsection{Numerical simulation}

The numerical simulations in this study were conducted using WRF-Chem version 3.6.1, which is an online-coupled chemical transport model considering multiple physical and chemical processes, including emission and deposition of pollutants, advection and diffusion, gaseous and aqueous chemical transformation, aerosol chemistry and dynamics (Grell et al., 2011). The model has been widely utilized to in- vestigate aerosol-radiation-cloud interactions and aerosolboundary-layer feedback (Grell et al., 2011; Zhao et al., 2013; Fan et al., 2015; Huang et al., 2015; Ding et al., 2016; Gao et al., 2016). In the present work, we adopted two nested model domains (Fig. 1a). The coarse domain is centered at $115.0^{\circ} \mathrm{E}, 33.0^{\circ} \mathrm{N}$ with a grid resolution of $20 \mathrm{~km}$ covered East China and its surrounding areas. The fine resolution of $4 \mathrm{~km}$ for the inner one allowed better characterization of small-scale physical processes, especially those linked to convective motions, cloud formation and rainfall onset. There were 31 vertical layers from the ground level to the top pressure of $50 \mathrm{hPa}, 20$ of which were placed below $4 \mathrm{~km}$ to achieve finer vertical resolution within the boundary layer. The initial and boundary conditions of meteorological fields were updated from the $6 \mathrm{~h}$ NCEP (National Centers for Environmental Prediction) global final analysis (FNL) data 
with a $1^{\circ} \times 1^{\circ}$ spatial resolution. To investigate the aerosols' radiative effects on 10 June 2012 when the precipitation was substantially modified, the simulations were conducted for the time period from 20 May to 15 June. The meteorological initializing date for 10 June was 12:00 UTC on 9 June. Each run covered $60 \mathrm{~h}$ and the last $48 \mathrm{~h}$ modeling results were kept for further analysis. The chemical outputs from the preceding run were used as the initial conditions for the following run. The first 20 days were regarded as the model spin-up period for atmospheric chemistry, so as to better characterize aerosol distributions and minimize the influences of initial conditions and allow the model to reach a state of statistical equilibrium under the applied forcing (Berge et al., 2001; Lo et al., 2008).

Key parameterization options for the WRF-Chem modeling were the Noah land surface scheme to describe the landatmosphere interactions (Ek et al., 2003), the YSU boundary layer scheme (Hong, 2010) and the RRTMG short- and longwave radiation scheme (Mlawer et al., 1997). The Lin microphysics scheme that accounts for six forms of hydrometer (Lin et al., 1983) together with the Grell cumulus parameterization was applied to reproduce the cloud and precipitation processes (Grell and Devenyi, 2002) for the coarse domain. Cumulus parameterization was switched off for the inner domain. For the numerical representation of atmospheric chemistry, we used the CBMZ (Carbon Bond Mechanism version Z) photochemical mechanism combined with MOSAIC (Model for Simulating Aerosol Interactions and Chemistry) aerosol model (Zaveri and Peters, 1999; Zaveri et al., 2008). Aerosols were assumed to be spherical particles. The size distribution was divided into four discrete size bins defined by their lower and upper dry particle diameters $(0.039-0.156$, $0.156-0.625,0.625-2.5$ and $2.5-10.0 \mu \mathrm{m})$. Aerosols in each size bin were assumed to be internally mixed and their optical properties, including extinction coefficient, single-scattering albedo (SSA) and asymmetry factor, were computed based on Mie theory (Fast et al., 2006) using volume averaged refractive indices (Barnard et al., 2010). Similar model configurations and settings have achieved good performance in our previous simulations over East China (Huang et al., 2015; Ding et al., 2016). Detailed configurations and domain settings are listed in Table 1.

Both natural and anthropogenic emissions were included for the regional WRF-Chem modeling in the present work. Typical anthropogenic emissions were obtained from the Multi-resolution Emission Inventory for China (MEIC) database ( $\mathrm{Li}$ et al., 2015), in which emissions sources were classified into five main sectors: power plants, residential combustion, industrial processes, on-road mobile sources and agricultural activities. This database covers most of anthropogenic pollutants, such as $\mathrm{SO}_{2}, \mathrm{NO}_{x}, \mathrm{CO}$, volatile organic compounds (VOCs), $\mathrm{PM}, \mathrm{BC}$ and $\mathrm{OC}$. $\mathrm{NH}_{3}$ emission over China was derived from Huang et al. (2012a). VOCs emitted from typical anthropogenic activities and aforementioned crop residue burning were speciated into model-ready
Table 1. WRF-Chem modeling configuration options and settings.

\begin{tabular}{lll}
\hline & $\begin{array}{c}\text { Domain setting } \\
\text { Domain 1 }\end{array}$ & Domain 2 \\
\hline Horizontal grid & $130 \times 130$ & $160 \times 160$ \\
Grid spacing & $20 \mathrm{~km}$ & $4 \mathrm{~km}$ \\
Vertical layers & 31 & 31 \\
& Configuration options & \\
Longwave radiation & RRTMG & \\
Shortwave radiation & RRTMG \\
Land surface & Noah & \\
Boundary layer & YSU \\
Microphysics & Lin et al. \\
Cumulus parameterization & Grell-Deveny & \\
& (only for domain 1) \\
Photolysis & Fast-J \\
Gas-phase chemistry & CBMZ \\
Aerosol scheme & MOSAIC \\
\hline
\end{tabular}

lumped species using profiles for Carbon Bond Mechanism (Hsu et al., 2006). The biogenic VOC and NO emissions were calculated online by using the Model of Emissions of Gases and Aerosols from Nature (MEGAN) that embedded in WRF-Chem (Guenther et al., 2006). More than 20 biogenic species, including isoprene, monoterpenes (e.g., $\alpha$-pinene and $\beta$-pinene) and sesquiterpenes, were considered and then involved in the photochemistry calculation. In China, crop residues are usually burned in piles, which are characterized by short-lived and small-scale smoldering. Consequently, the plume rise of biomass-burning plumes was not considered in this study, and the straw fire emission was placed in the lowest two levels from the surface to around $50 \mathrm{~m}$ in this simulation.

Previous studies have shown that, under highly polluted conditions, the aerosol-radiation interaction (ARI) dominated over the aerosol-cloud interaction (ACI) that is related to aerosols' ability to act as cloud condensation nuclei (CCN) (e.g., Rosenfeld et al., 2008; Fan et al., 2015). We also conducted another numerical experiment which included both ACI and ARI. The ACI-induced radiative perturbations were much less notable than those caused by ARI both at the surface and in the atmosphere (Fig. S2), implying the dominant role of ARI during this kind of synoptic-scale fire event. Since that the focus of this study is on ARI and ACI's effect was not that significant, the prognosed aerosol was disabled to act as $\mathrm{CCN}$ or ice nuclei in the simulations and therefore the effects from ACI were not accounted for in the following analysis. Accordingly, wet scavenging of aerosol was disabled too. In order to disentangle aerosols' role in radiative transfer and subsequent effects on cloud and precipitation during this biomass-burning event in mid-June of 2012, we designed three parallel numerical experiments. Domain settings and model configurations for these simulations were exactly the same as mentioned before. The control 
(CTL) experiment did not include aerosol's effects on either longwave or shortwave radiation transfer. On the contrary, the other two took account of aerosols' perturbations on radiation transfer: ARI-A with anthropogenic emissions (anthropogenic activities refer to power generation, transportation, industrial and residential activities hereafter) and ARIAB that included both anthropogenic activities and biomassburning emissions.

\section{Results and discussions}

\subsection{Fire-induced pollution and observed anomalies in meteorology}

As demonstrated by existing studies (Andreae et al., 1988; Huang et al., 2012c; Ding et al., 2013a), air quality dramatically deteriorated and the visibility was impeded during biomass-burning events. We compare the simulated daily averaged $\mathrm{PM}_{10}$ concentration with the corresponding measurements derived from Air Pollution Index (API, available at http://datacenter.mep.gov.cn/) in Fig. 3 (if not mentioned specially, the simulation refers to ARI-AB experiment hereafter). Both observations and simulations manifested the fact that intensive agricultural fires led to the severe pollution in mid-June. Since 9 June, when the detected fire spots became intense and extensive, $\mathrm{PM}_{10}$ concentrations in northern Anhui and northwestern Jiangsu province began to increase, especially for those regions near the fire location. For instance, the observed daily mean $\mathrm{PM}_{10}$ concentrations reached up to around $250 \mu \mathrm{g} \mathrm{m}^{-3}$ at Fuyang (FY) and Xuzhou (XZ) and even exceeded $400 \mu \mathrm{g} \mathrm{m}^{-3}$ at Bengbu (BB) on 9 June (the locations of cities mentioned in this article are labeled in Fig. 2). Although the simulated temporal variations agree with observations, model-predicted $\mathrm{PM}_{10}$ concentrations at FY and BB were 196 and $168 \mu \mathrm{g} \mathrm{m}^{-3}$ respectively. The underestimation might be due to the fact that rapid formation of secondary aerosol like sulfate and secondary organic matters is not so well described in current atmospheric chemical transport models (Capes et al., 2008; Xie et al., 2015). $\mathrm{XZ}$ and $\mathrm{BB}$ suffered from the second-round fire smoke 2 days later, with a maximum daily mean concentration of $548 \mu \mathrm{g} \mathrm{m}^{-3}$ observed at BB. Figure 4 illustrates the satelliteretrieved $660 \mathrm{~nm}$ aerosol optical depth (AOD) and SSA from MODIS Aerosol Product MOD04_L2 (daily level 2 data produced at the spatial resolution of $10 \mathrm{~km}$, Collection 6) around 11:00 local time (LT) on 9 June when the first round of extensive fire pollution broke out. Their comparisons with ARI$\mathrm{AB}$ modeled spatial distributions of $\mathrm{PM}_{2.5}$ and $\mathrm{BC}$ columnintegrated mass loadings further confirm model's ability to reproduce atmospheric pollution for this event. The AOD observation shows that high aerosol loadings were concentrating in northeast Anhui and the north-central Jiangsu, shaping a belt of pollution from the fire sites to the downwind areas. A similar pattern was also simulated by the model. The $\mathrm{PM}_{2.5}$
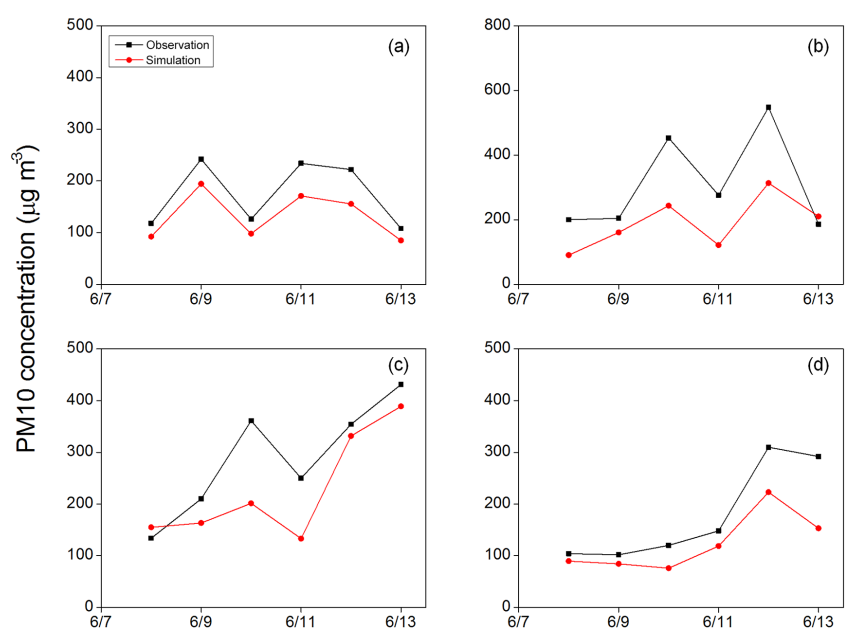

Figure 3. Measurements of $24 \mathrm{~h}$ averaged $\mathrm{PM}_{10}$ concentrations and corresponding $\mathrm{PM}_{10}$ simulations at (a) FY (Fuyang), (b) BB (Bengbu), (c) XZ (Xuzhou) and (d) HF (Hefei).

mass loading was found to exceed $200 \mathrm{mg} \mathrm{m}^{-2}$ near BB, NJ and most parts of central Jiangsu. This strap-shaped pollution was particularly obvious in terms of BC column concentrations, which was also consistent with a relatively lower SSA along BB, Yangzhou (YZ) and Taizhou (TZ). While solely including anthropogenic emissions, ARI-A experiment failed to represent the spatial pattern of high AOD in the northern Anhui and Jiangsu and the low SSA value near BB (Fig. 4a, d).

Along with the severe air pollution and poor visibility, anomalies in meteorology occurred on 9-10 June. Ding et al. (2013a) found that, during these 2 days, a sharp decline existed in the observed air temperature in NJ and YZ compared with weather forecast results and NCEP FNL data, but the simulations and observations showed a good agreement when the heavy air pollution was not present before 9 June and after 10 June. At YZ the temperature difference was as high as 5.9 and $9.2^{\circ} \mathrm{C}$ on 9 and 10 June respectively. Simultaneously, measured solar radiation intensity and sensible heat flux showed very low values on 10 June in comparison with non-episode days. Moreover, local meteorological agency forecasted a convective rainfall to occur in $\mathrm{NJ}$ and surrounding areas in the afternoon of 10 June, with the rainfall center passing by $\mathrm{NJ}$ around 14:00 LT. However, this forecasted rainfall never happened that day.

On the basis of ground-based measurements, vertical sounding data, remote-sensing images and their comparisons with numerical simulations, we found that agricultural fires worsen regional air quality to a large extent and caused a series of anomalies in temperature and precipitation in the mid-June of 2012. How the biomass-burning plumes influenced the air temperature and precipitation will be the main issue to be addressed in the following discussions. 
(a)

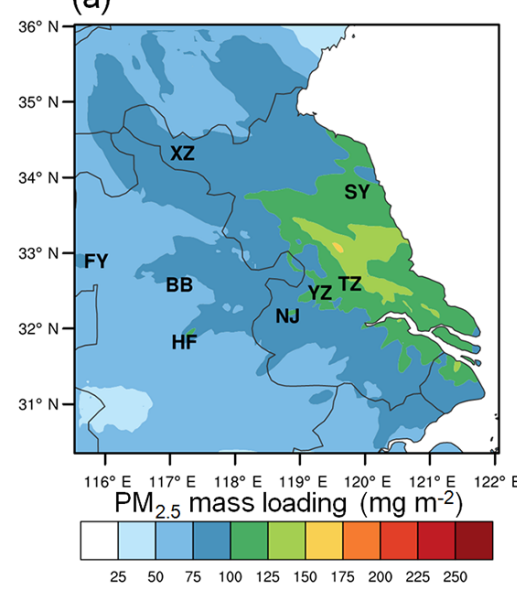

(d)

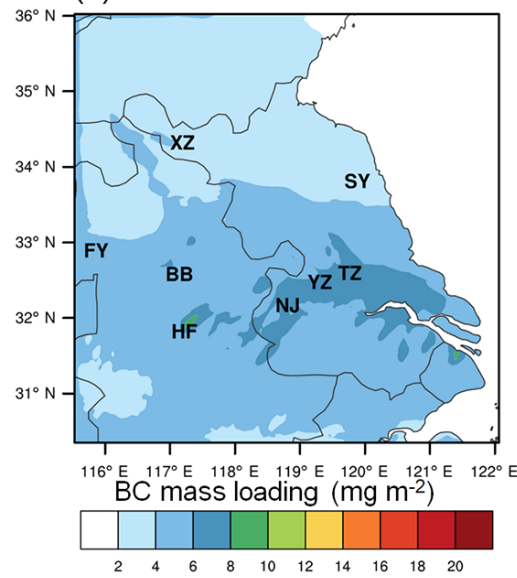

(b)

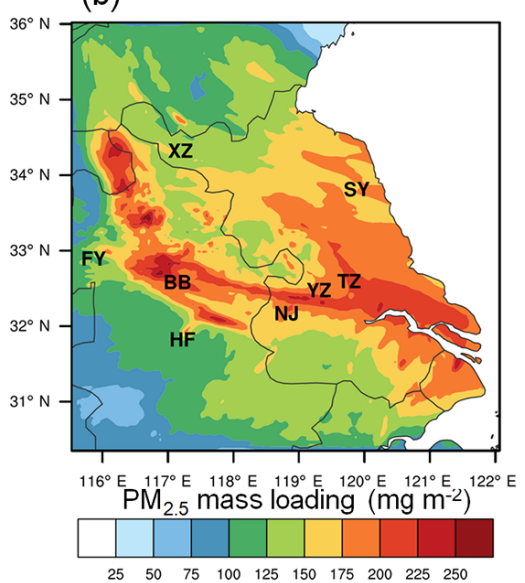

(e)

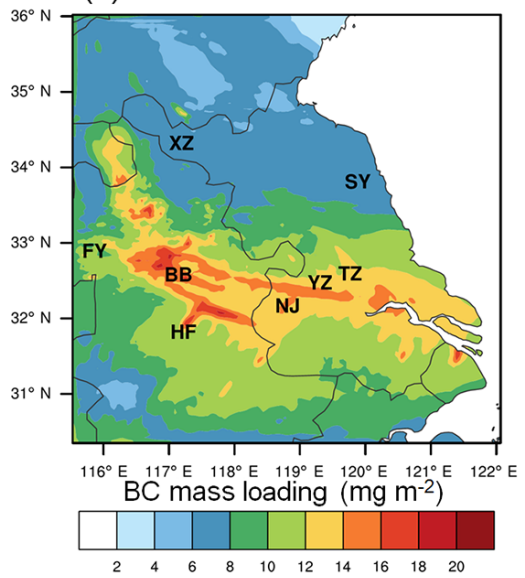

(c)

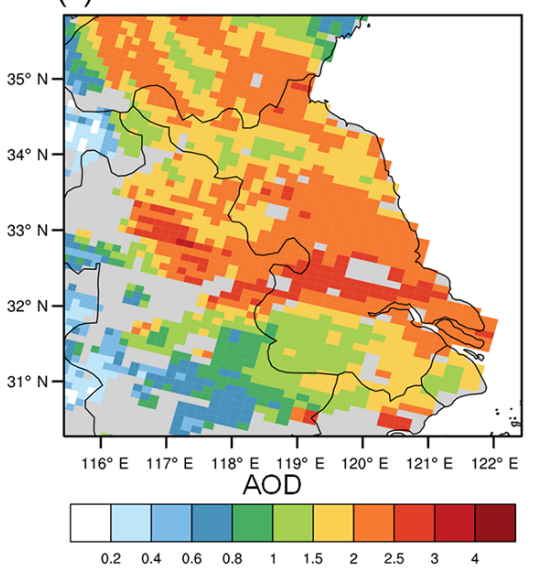

(f)

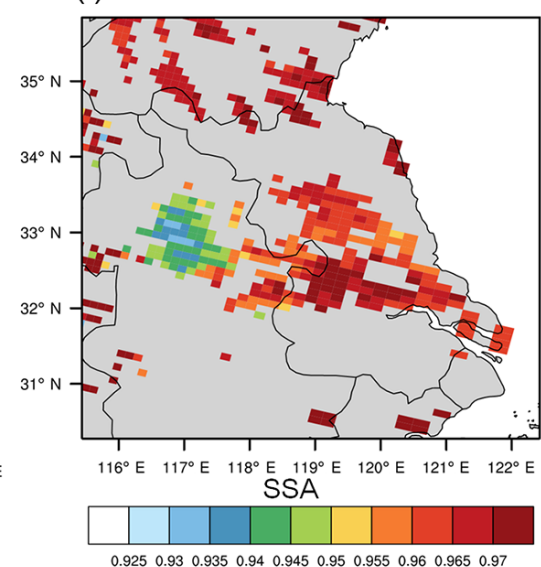

Figure 4. Spatial distributions of simulated $\mathrm{PM}_{2.5}$ mass loading by (a) ARI-A and (b) ARI-AB experiments and (c) satellite-derived $660 \mathrm{~nm}$ AOD at 11:00 LT, 9 June. Simulated BC mass loading by (d) ARI-A and (e) ARI-AB experiments and (f) satellite-derived SSA at that time.

\subsection{Perturbations in energy budget and temperature responses}

To better understand aerosols' role in the energy re-allocation on 10 June when precipitation was evidently modified, radiative forcing in the atmosphere and at the ground surface was estimated by differentiating the CTL, ARI-A and ARI$\mathrm{AB}$ simulations (Fig. 5). At the surface, daily mean incident shortwave radiation was weakened by $45.5 \mathrm{~W} \mathrm{~m}^{-2}$ (averaged over the inner domain) as the extinction of aerosol was quite large with a satellite-observed $660 \mathrm{~nm}$ AOD exceeding 2.0 (Fig. 4b). Meanwhile, about $60.4 \mathrm{~W} \mathrm{~m}^{-2}$ shortwave energy was blocked in the atmosphere over the inner domain due to the fact that absorbing aerosols were accumulated on that day. A positive domain-averaged radiative forcing of $+14.9 \mathrm{~W} \mathrm{~m}^{-2}$ was simulated at the top of the atmosphere on 10 June. Comparatively, radiative perturbations caused by agricultural fires (ARI-AB minus ARI-A) were more substantial than those due to anthropogenic emissions (ARI-A minus CTL) in magnitude, particularly in the atmosphere, as presented in Fig. 5. Spatially, radiative effects due to anthropogenic activities concentrated in the economically developed Yangtze River Delta region while agricultural fires exerted significant impact on radiation balance in northern and central Jiangsu and the northern part of Anhui. Table 2 compares the radiative perturbations caused by anthropogenic activities and biomass-burning emissions over three regions with distinct precipitation changes (marked in Fig. 8). As shown, both of them tended to heat the atmosphere and cool the ground surface. Fire plumes dominated the radiative effect in terms of atmospheric warming. Radiation measurements collected at Hefei (HF) and sensible and latent heat flux recorded at Lishui (in South Nanjing) are compared with the diurnal variations of corresponding simulations in Fig. 6, which supports that significant radiative perturbations took place at NJ and HF. Substantially weakened daytime solar irradiance was observed on 10 June, when the peak value of downwelling shortwave radiation was $618.3 \mathrm{~W} \mathrm{~m}^{-2}$ at $\mathrm{HF}$ and was only $309.7 \mathrm{~W} \mathrm{~m}^{-2}$ at NJ. Taking aerosol's effect on radiation into account tended to predict lower downwards solar radiation, which was closer to obser- 
vation for both cities. Reduction in shortwave energy hitting the surface in turn decreased outgoing heat fluxes and therefore simulated sensible and latent heat fluxes at 12:00 LT on 10 June in ARI-AB experiment decreased by 89.3 and $76.1 \mathrm{~W} \mathrm{~m}^{-2}$, respectively, compared to the CTL experiment.

Overall, the magnitude of the radiative forcing on 10 June was comparable in northern Anhui and central Jiangsu, differing from the distribution pattern of fire-induced air pollution that remarkably concentrated in northern Anhui. As revealed in our previous estimation, among all components of the ambient aerosols, BC is the most important disturber of shortwave radiation transfer at the surface and in the atmosphere as well (Huang et al., 2015; Ding et al., 2016). Although fire emission mostly concentrated in the northern Anhui and resulted in a high BC concentration of $20 \mu \mathrm{g} \mathrm{m}^{-3}$ there, high-altitude BC was spread much more broadly. At an altitude of $2 \mathrm{~km}, \mathrm{BC}$ concentration around $5 \mu \mathrm{g} \mathrm{m}^{-3}$ stretched from northern Anhui to central Jiangsu (Fig. S3). Such distinct distributions between two layers were partly attributed to the stagnant condition near the surface and stronger horizontal transport in the upper level. It is emphasized that upper-level BC has higher absorbing efficiency (Ding et al., 2016). That is why the distributions of both positive radiative forcing in the atmosphere and negative forcing at the surface were generally consistent with BC's spatial pattern in the upper air.

The perturbations in the energy budget and the following re-allocation gave rise to substantial modulation in vertical stratification of air temperature. In comparison with the CTL experiment, ARI-AB experiment predicted an obvious decline in near-surface temperature by considering the effects of aerosol-radiation interaction. Hourly observed $2 \mathrm{~m}$ air temperature was compared with corresponding simulations by two experiments during the time period from 8 to 15 June. Model-performance statistics including mean bias, mean error and root mean square error are presented in Table 3. As shown, CTL simulation had a systematic positive bias in $2 \mathrm{~m}$ temperature and ARI-AB predicted lower temperature for both areas near fire locations (BB and XZ) and downwind regions (NJ and SY). The decreases in temperature were pronounced in $\mathrm{BB}$ and $\mathrm{XZ}$ with a large difference of approximately $1.2^{\circ} \mathrm{C}$, which notably narrowed the gaps with observations. On 10 June when the fire-induced pollution became intensive, the magnitude of surface cooling was remarkably high near the fire sites. Temperature response in Fig. 5e support this cooling effect. For instance, compared to CTL, simulated near-surface temperature by ARI-A and ARI-AB experiment at $\mathrm{XZ}$ was cooled by almost 1.2 and $8.0^{\circ} \mathrm{C}$ at $20: 00 \mathrm{LT}$ on $10 \mathrm{June}$ (Fig. $7 \mathrm{~b}$ ). In addition to the cooling tendency of near-surface temperature, aerosols' radiative effects also increased air temperature at a higher altitude, which were more apparent over the downwind areas (Fig. 5f). According to the comparisons between simulated temperature profiles by the three parallel experiments in Fig. 7, the warming of air temperature was particularly evident around an altitude of $2 \mathrm{~km}$ at $\mathrm{SY}$ with a maximum of $3.0^{\circ} \mathrm{C}$, and the biomass-burning aerosols played a leading role.

The different temperature responses over the source region of fire emission and downwind areas could be partially interpreted by the fact that, near the fire locations, pronounced surface cooling counteracted part of the atmospheric warming, which would otherwise elevate upper-air temperature, through vertical mixing; for the downwind area where the surface was less radiatively cooled, the atmosphere was prone to being warmed. As a result of surface cooling and atmospheric heating, vertical convective motions were weakened, triggering perturbations in pressure and wind fields (Fig. 5e and f). It is obvious that suppressed convection was generally along with the resultant wind convergence around $2 \mathrm{~km}$ and surface divergence, which may further play a significant role in water vapor transport, entrainment and also cloud formation.

\subsection{Effects on cloud and precipitation}

In addition to the attenuation of solar radiation and the modulation in temperature gradients, precipitation also showed many disparities between CTL and ARI-AB simulations. The satellite observation from Tropical Rainfall Measuring Mission (TRMM) Multisatellite Precipitation Analysis product (3B42), which provides merged-infrared precipitation information at a $0.25 \times 0.25^{\circ}$ spatial resolution and has been demonstrated to perform well in East China (Simpson et al., 1988; Zhao and Yatagai, 2014), was used to evaluate the simulated precipitation. As demonstrated in Fig. 8, ARI-AB experiment agrees better with TRMM observations than CTL experiment in terms of precipitation intensities and also spatial pattern on 10 June. Specifically, CTL and ARI-A simulation suggested a convective rain in Zone 1 (NJ and its adjacent areas) around 14:00 LT (the locations of zones 13 are marked in Fig. 8); however the ARI-AB simulation did not show any precipitation then, consistent with the TRMM observations. Besides, ARI-AB displayed enhanced precipitation in northern Jiangsu province. A precipitation with the intensity of 3 and $5 \mathrm{~mm} \mathrm{~h}^{-1}$ was predicted by ARI-AB experiment in Zone 2 (XZ and its adjacent areas) and Zone 3 (SY and its adjacent areas), which, however, never occurred in the CTL and ARI-A experiments. Concerning temporal variations, $3 \mathrm{~h}$ precipitation rates for these three zones derived from TRMM 3B42 retrievals are plotted in Fig. 9. Compared to the CTL and ARI-A experiments, the ARI-AB experiment, which considered radiative effects of aerosol from both anthropogenic and biomass-burning emissions, succeeded in capturing the approximate onset time for all the three regions.

\subsubsection{Suppressed daytime precipitation}

Over Zone 1, CTL and ARI-A simulations produced a convective rainfall event in the afternoon that actually did not 

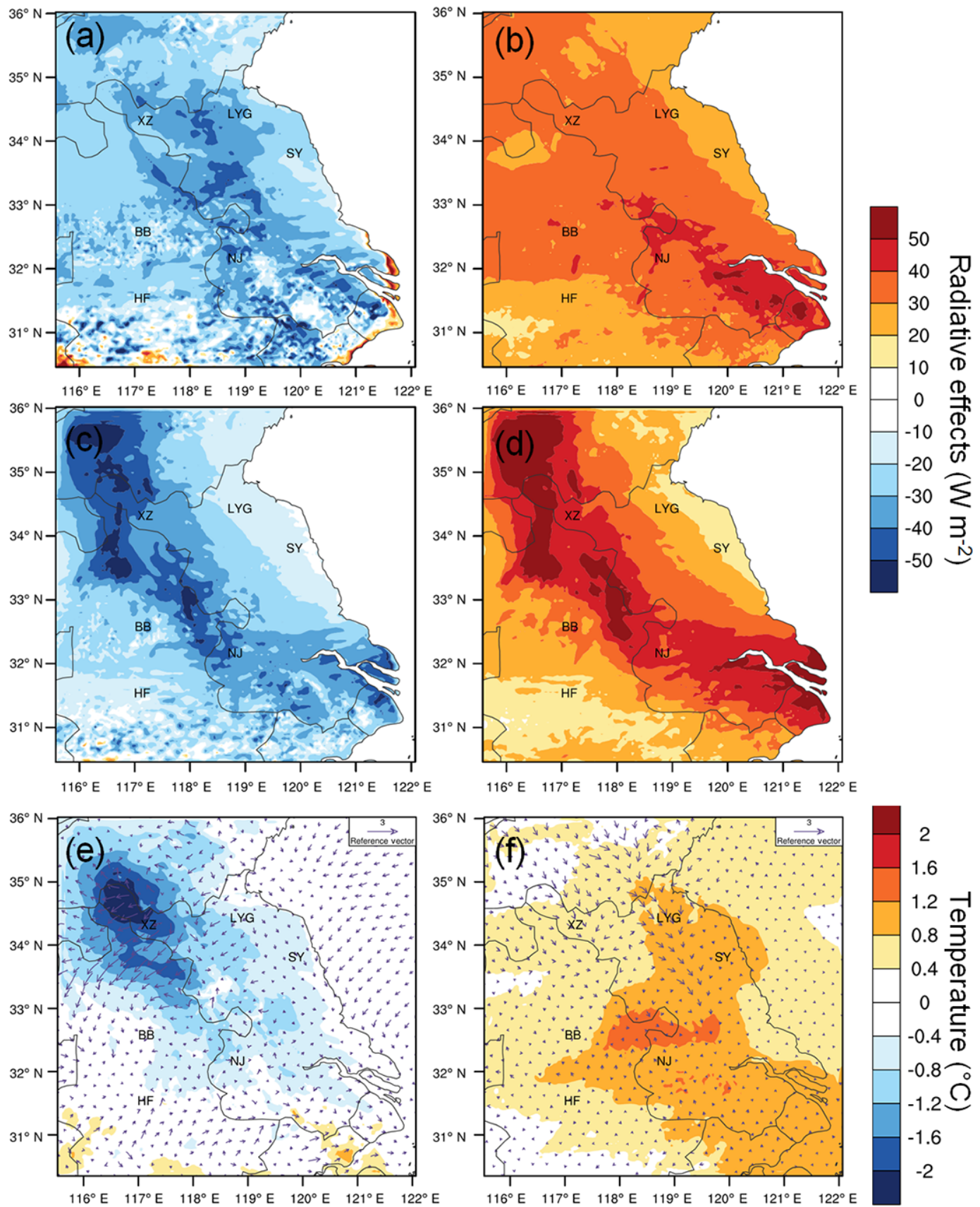

Figure 5. Radiative forcing (a) at the surface and (b) in the atmosphere due to anthropogenic aerosols on 10 June. Radiative forcing of aerosol (c) at the surface and (d) in the atmosphere due to biomass-burning emissions on 10 June. Aerosol-induced changes in air temperature and wind fields (e) near the surface and (f) at the altitude of $2 \mathrm{~km}$.

happen, while ARI-AB simulation with no precipitation was closer to the observations. According to the energy budget and radiation flux calculation (Fig. 5), on 10 June more than $6 \mathrm{MJ} \mathrm{m}^{-2}$ solar radiation that was supposed to reach the surface was blocked in the atmosphere over Zone 1, most of which was caused by biomass-burning aerosol. The presence of light-absorbing aerosols reduced sensible heat flux and evapotranspiration at the surface (Fig. 6). Large-eddy sim- ulation for biomass-burning regions of Brazil deduced that the peak reductions in sensible and latent heat flux were 60 and $70 \mathrm{~W} \mathrm{~m}^{-2}$ (Feingold et al., 2005), which are quantitatively similar to those near $\mathrm{NJ}$ estimated in this work. It was shown that reduced surface flux alone was sufficient to explain the observed cloud dissipation during the biomassburning event in Brazil. For this case, this convective rain disappeared merely by nudging $2 \mathrm{~m}$ temperature in the WRF 
Table 2. Radiative perturbations at the surface (SUR) and in the atmosphere (ATM) caused by anthropogenic activities and agricultural fires for three zones with distinct precipitation changes.

\begin{tabular}{ccc|cc}
\hline & \multicolumn{2}{c}{ SUR } & \multicolumn{2}{c}{ ATM } \\
\cline { 2 - 5 } & Anthropogenic activities & Agricultural fires & Anthropogenic activities & Agricultural fires \\
\hline Zone 1 & -27.3 & -35.1 & 36.3 & 41.1 \\
Zone 2 & -33.3 & -41.7 & 31.9 & 45.6 \\
Zone 3 & -23.8 & -14.8 & 27.7 & 21.1 \\
\hline
\end{tabular}
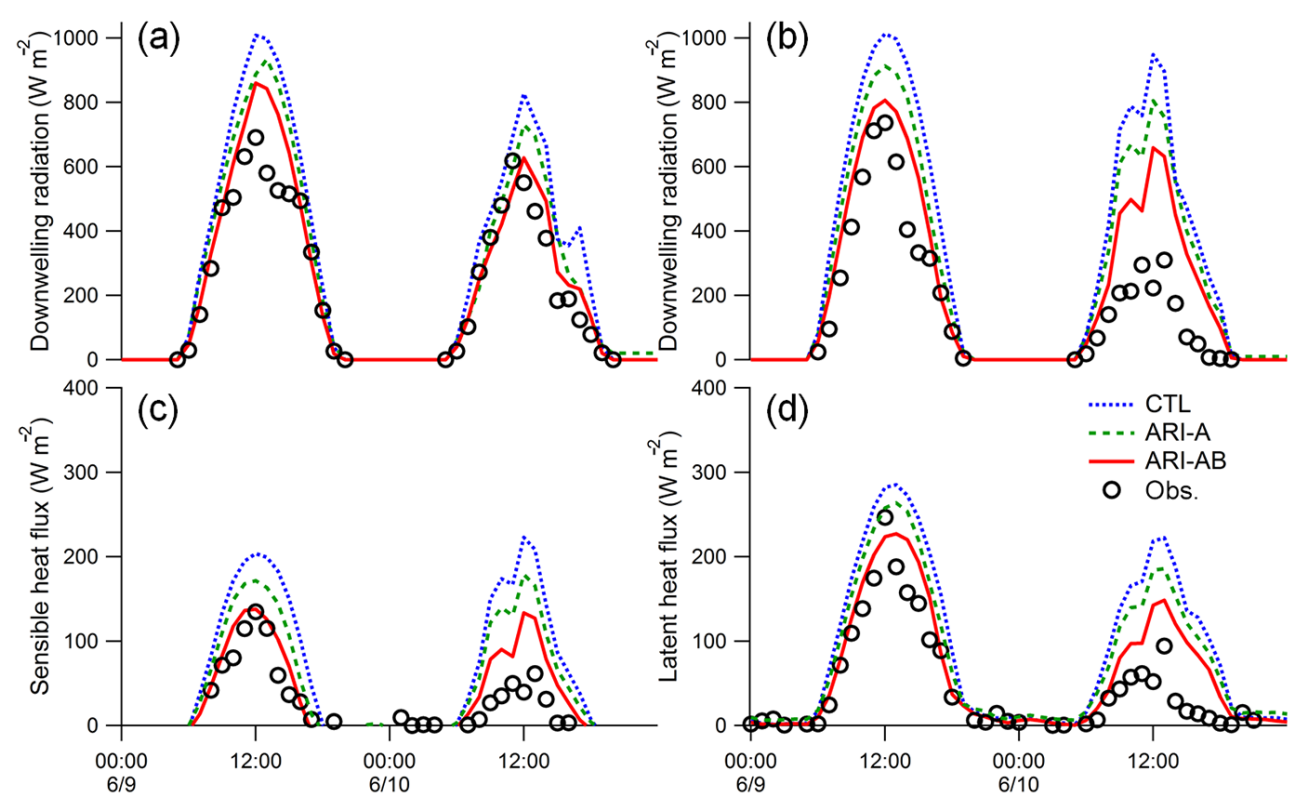

Figure 6. Diurnal variations of simulated and observed downwelling shortwave radiation at (a) HF (Hefei) and (b) NJ (Nanjing) on 910 June. Comparisons of (c) simulated sensible and (d) latent heat fluxes with the measurements at NJ. Blue, green and red lines present the CTL, ARI-A and ARI-AB experiments. Black circles mark the observations.

Table 3. Statistical analyses of the simulated $2 \mathrm{~m}$ temperature and the corresponding observations at four different cities.

\begin{tabular}{lrr|rc|cc}
\hline & \multicolumn{2}{c|}{ MB* $^{*}$} & \multicolumn{2}{c|}{ ME$^{*}$} & \multicolumn{2}{c}{ RMSE* } \\
\cline { 2 - 6 } & \multicolumn{1}{c}{ CTL } & ARI-AB & CTL & ARI-AB & CTL & ARI-AB \\
\hline NJ & 0.85 & 0.37 & 1.70 & 1.66 & 2.39 & 2.15 \\
BB & 2.19 & 0.98 & 2.51 & 1.65 & 3.27 & 2.16 \\
XZ & 1.67 & 0.51 & 2.37 & 2.19 & 3.32 & 2.89 \\
SY & -0.28 & -0.46 & 1.97 & 1.65 & 2.52 & 2.03 \\
\hline
\end{tabular}

* MB, ME and RMSE refer to mean bias, mean error and root-mean-square error respectively.

modeling run by Ding et al. (2013a), highlighting the importance of surface flux modification in the development of these convective clouds.

To figure out the role of vertical thermal behaviors in Zone 1, temporal variations of zone-averaged differences in temperature, relative humidity $(\mathrm{RH})$ profiles between ARI$\mathrm{AB}$ and $\mathrm{CTL}$ experiments are illustrated in Fig. 10a and $\mathrm{b}$.
From 09:00 LT in the morning, a $1 \mathrm{~km}$ thick belt with BCladen smoke approached Zone 1 and covered the boundary layer top. The radiative extinction by the elevated smoke layer led to a cooling effect at the surface, which reduced the boundary layer height and decreased the air temperature in the boundary layer. Simultaneously, relatively strong warming effect between the altitudes of $1-3 \mathrm{~km}$ increased the air temperature above the boundary layer. The cooling at the lower altitude and warming at the upper altitude made the stability significantly increase, especially near the top of the boundary layer, which further suppressed the development of boundary layer. For the perturbations in humidity, the enhanced atmospheric stability reduced the boundary layer height and hindered the upward transport of water vapor to a higher altitude, while the heating aloft decreased RH by increasing the air temperature there. These led to a resultant decrease of more than $20 \%$ in RH above the boundary layer. A more stable and shallower boundary layer in ARI-AB experiment had a tendency to reduce convective mixing and effectively cut off the cloud layer from its source of moisture, sub- 

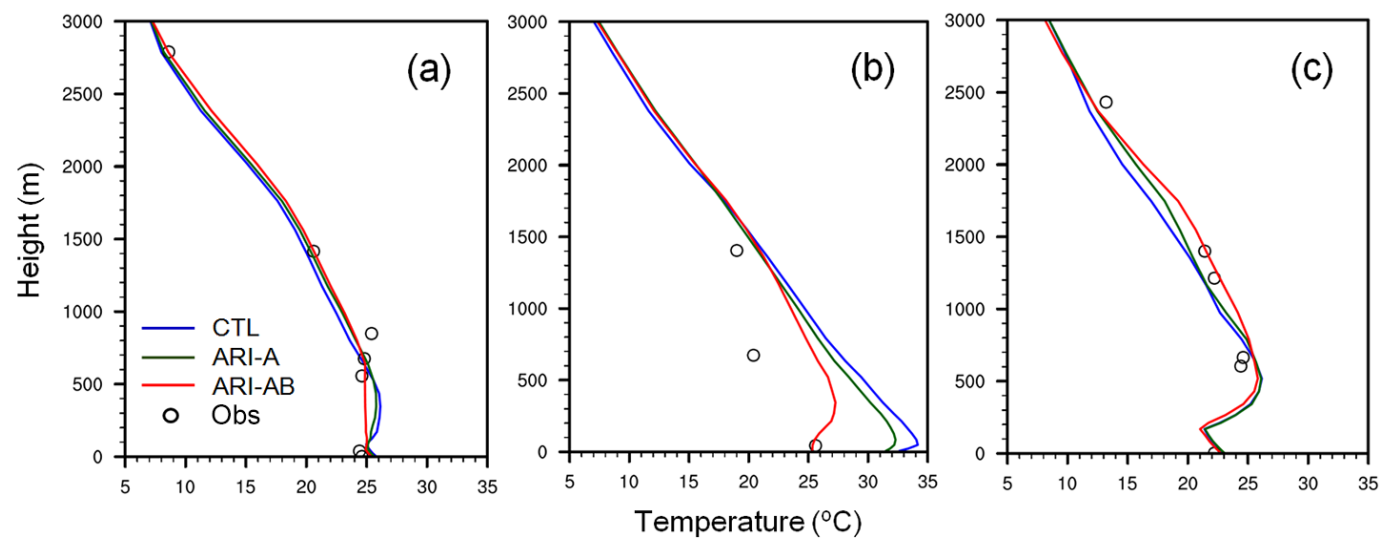

Figure 7. Comparisons between the observed and modeled air temperature profiles for (a) NJ (Nanjing) at 08:00 LT and (b) XZ (Xuzhou) and (c) SY (Sheyang) at 20:00 LT, 10 June. Black circles denote sounding observations. Blue, green and red solid lines are experiments without (CTL) and with radiative effects of aerosols from anthropogenic emissions (ARI-A) and additional fire emissions (ARI-AB) respectively.

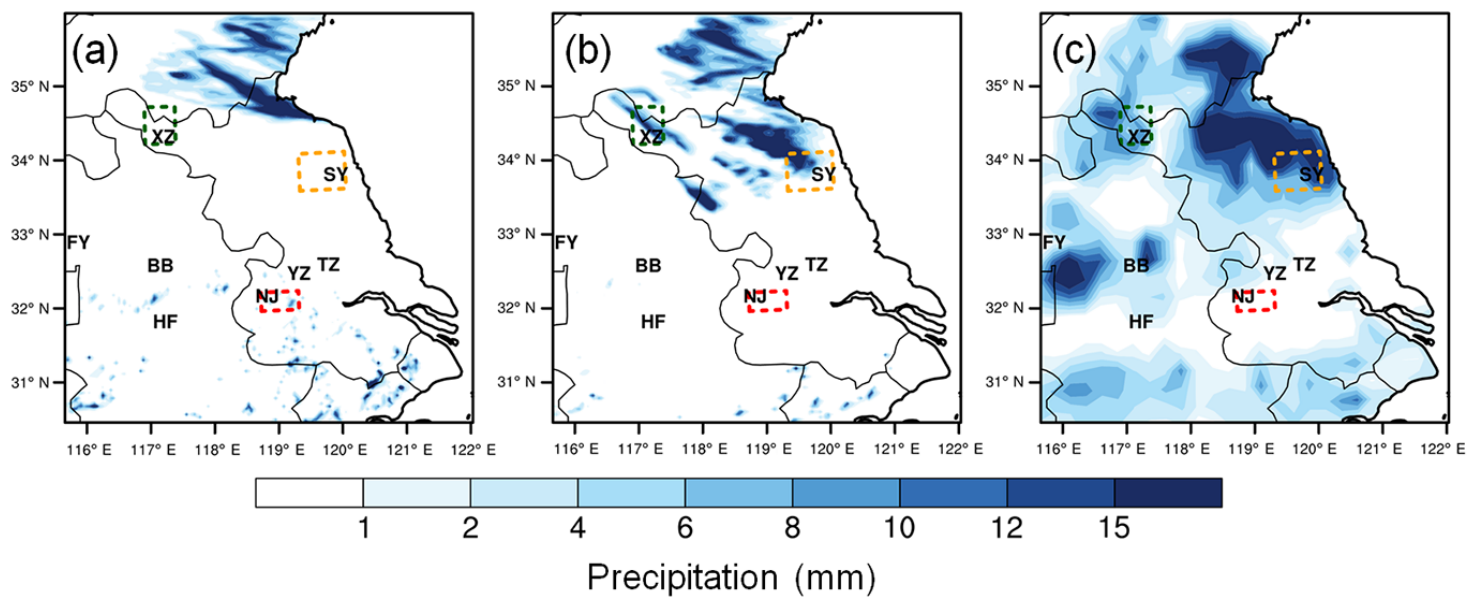

Figure 8. Modeled precipitation during the period from 00:00 UTC, 10 June, to 00:00 UTC, 11 June, while excluding and considering radiative effects of aerosols in (a) CTL and (b) ARI-AB experiments, corresponding to (c) TRMM-observed precipitation. Three regions with notable changes in precipitation are marked in rectangles: Zone 1 (red dashed line), Zone 2 (green dashed line) and Zone 3 (yellow dashed line).

sequently desiccating the cloud layer, and leading to substantially weakened vertical motions. Accordingly, ARI-AB simulated updraft velocity above $1 \mathrm{~km}$ was only one-tenth that of CTL experiment in the afternoon of 10 June, as demonstrated in Fig. 10f. Even though anthropogenic aerosol also weakened convective motions in ARI-A experiment, the potential temperature profile was hardly changed and the weakening effect of convection was not comparable with that caused by biomass-burning aerosols. Therefore, compared with CTL and ARI-A experiment, much less moist static energy (MSE) was carried upwards and the excess MSE accumulated in a shallower boundary layer due to much weaker convection in ARI-AB experiment (Fig. 10e).

In addition to Zone 1, this warmed belt was also blanketing a wider range from 116 to $120^{\circ} \mathrm{E}$ at the moment when the CTL-predicted rainfall started (Fig. 9a shows that the rainfall occurred around 14:00 LT), as shown in the longitude-height cross sections of temperature difference between the CTL and ARI-AB experiments in Fig. 10c. In the CTL run, a cumulus cloud layer appeared above the inversion, capping the boundary layer (Fig. 10d). However, the absorbing aerosol in ARI-AB run heated the atmosphere aloft and stabilized the sub-cloud layer. The decrease in specific humidity was collocated with warmed upper air since that atmospheric heating and surface cooling weakened vertical convection and further reduced the vertical transport of water vapor. Lower entrainment rate together with higher saturation pressure resulted in daytime decoupling and thinning of the cloud layer all along the longitude from 116 to $120^{\circ} \mathrm{E}$. This effect might be further strengthened by a positive feedback loop as described by Jacobson (2002), in which cloud loss leads to an increasing opportunity for BC's light absorption. 

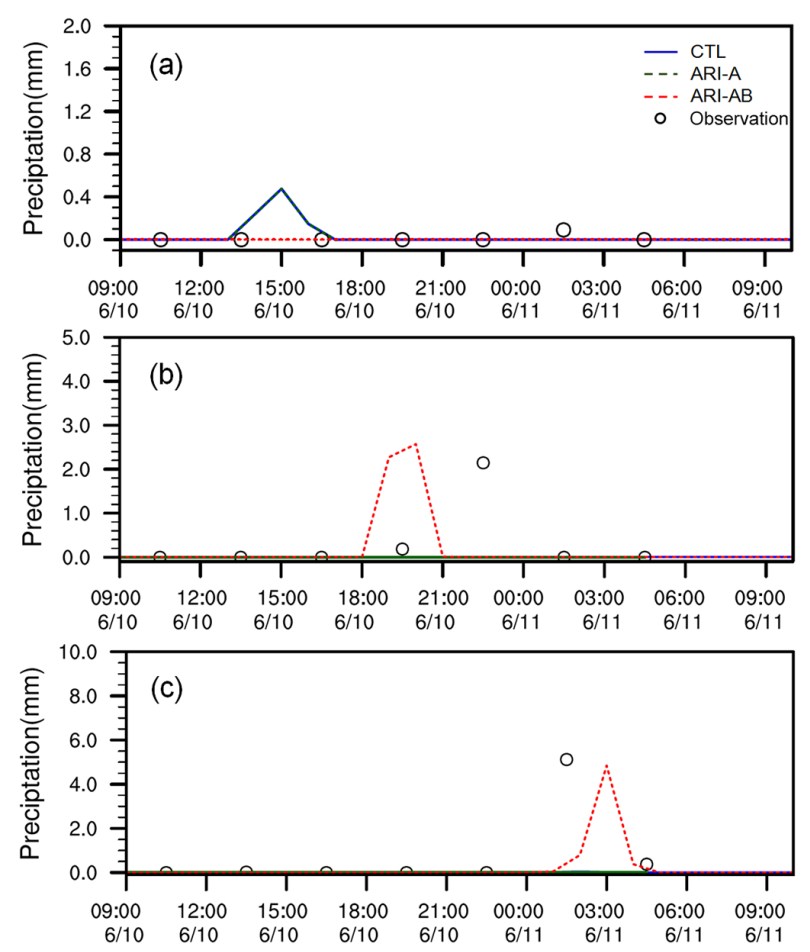

Figure 9. Simulated hourly precipitation while considering (ARIA experiment in green dashed lines; ARI-AB experiment in red dashed lines) and excluding (blue solid lines, CTL) radiative effects of aerosols and their comparisons with TRMM observations (black circles) for (a) Zone 1, (b) Zone 2 and (c) Zone 3.

\subsubsection{Enhanced nocturnal precipitation}

A precipitation rate of over $2.5 \mathrm{~mm} \mathrm{~h}^{-1}$ was observed around 19:00-20:00 LT on 10 June in XZ and its surrounding areas (Zone 2). Only ARI-AB simulation captured this precipitation event. As shown in Fig. 11a, there existed two layers with a high $\mathrm{BC}$ concentration of up to $10 \mu \mathrm{g} \mathrm{m}^{-3}$ during daytime over Zone 2. One was near the surface and peaked around 18:00 LT, which could be linked to local fire emissions. The other one was lying over the boundary layer top, which was apparent at an altitude of $0.8 \mathrm{~km}$ before the boundary layer developed and at $2 \mathrm{~km}$ after 15:00 LT. It was very likely associated with the transport of upstream fire pollution. Owing to strong radiative heating effect of $\mathrm{BC}$, a warmer layer was formed above $1 \mathrm{~km}$ during daytime with temperature increase over $1.0^{\circ} \mathrm{C}$. In contrast, near-surface temperature kept decreasing. The decline reached its maximum around 20:00 LT. It was also supported by Fig. 7b in which the near-surface temperature decreased by almost $8.0^{\circ} \mathrm{C}$ at XZ. Until 16:00 LT, the upper-air warming due to radiative absorption was gradually compensated by cooling from the surface through vertical mixing. Changes in RH were almost opposite of those in air temperature. Around 18:00 LT, RH at $3 \mathrm{~km}$ altitude started to increase and then a precipitating cloud formed there.
To get a better insight into the dynamical processes that contribute to precipitation change, longitude-height cross section of zonal mean responses of temperature, water vapor and wind profile just before the onset time of precipitation are demonstrated in Fig. 11c and d. Noteworthy is that warmed upper air between 117 and $119^{\circ} \mathrm{E}$ led to less condensation there. More water vapor accumulated below $1 \mathrm{~km}$ and was then transported toward Zone 2 by the prevailing east wind near the surface, leading to excess water vapor over Zone 2 in the ARI-AB experiment (Fig. 11e). Simultaneously, radiatively heated air parcel with a temperature increase of $0.5^{\circ} \mathrm{C}$ was found around $2 \mathrm{~km}$ over Zone 2 . The warmer layer around $2-3 \mathrm{~km}$ combined with large drops in temperature beneath resulted in a buoyancy-driven lifting force. Moreover, horizontal heterogeneity in atmospheric heating provided the low-level convergence for maintaining convection in a conditionally unstable atmosphere around $3 \mathrm{~km}$. The zone-averaged updraft velocity in ARI-AB experiment tripled that predicted by CTL and ARI-A at the altitude of $3 \mathrm{~km}$ when the precipitation began (Fig. 11f). Understandably, what made the precipitating cloud form around $3 \mathrm{~km}$ over Zone 2 was the accumulated MSE near the surface and anomalous updraft of the air that favored the vertical uplift of MSE. The release of latent heat may increase the upperair instability and in turn enhance the precipitation.

For the downwind region Zone 3, the warming effect caused by aerosol-radiation interaction was evident for the air column above $0.5 \mathrm{~km}$ all day long on 10 June (Fig. 12a). The warming pattern was coincident with the distribution of $\mathrm{BC}$ concentration. As a result of increased air temperature, $\mathrm{RH}$ decreased substantially during daytime. Late at night, an extra precipitating cloud formed above $2 \mathrm{~km}$ over Zone 3 in ARI-AB simulation, leading to a nocturnal precipitation with a strength of approximately $6 \mathrm{~mm} \mathrm{~h}^{-1}$ at 01:00 LT on 11 June. What triggered this rainfall event is a bit more complicated than that over Zone 2. First, the whole air column was cooling at the moment when the precipitation took place, inevitably raising the $\mathrm{RH}$ value. The $\mathrm{RH}$ increase was quite apparent at the altitude of $3-4 \mathrm{~km}$. Second, daytime radiative absorption by BC-laden plumes around $2 \mathrm{~km}$ heated the surrounding air. Relatively warmer layer at the altitude of $\sim 2 \mathrm{~km}$ generated a positive buoyant updraft (Figure 12f) hence the air parcel there was displaced upwards along with enhanced convergence carrying in moist air. This effect has been proposed by Fan et al. (2015) as part of termed "enhanced conditional instability", by which absorbing aerosols escalate convection downwind of a heavily polluted area and promote precipitation. Comparatively, radiative heating of biomass-burning aerosol was the main contributor to the significant enhancement of upper-level updraft. Last but not the least, spatially heterogeneous aerosol-related heating was associated with greater horizontal temperature lapse, resulting in a convergence flow above $3 \mathrm{~km}$ with an additional onshore wind (Fig. 12d). Zone 3 is only about $20 \mathrm{~km}$ from the Yellow Sea. It is plausible that more water vapor-saturated air 
(a)
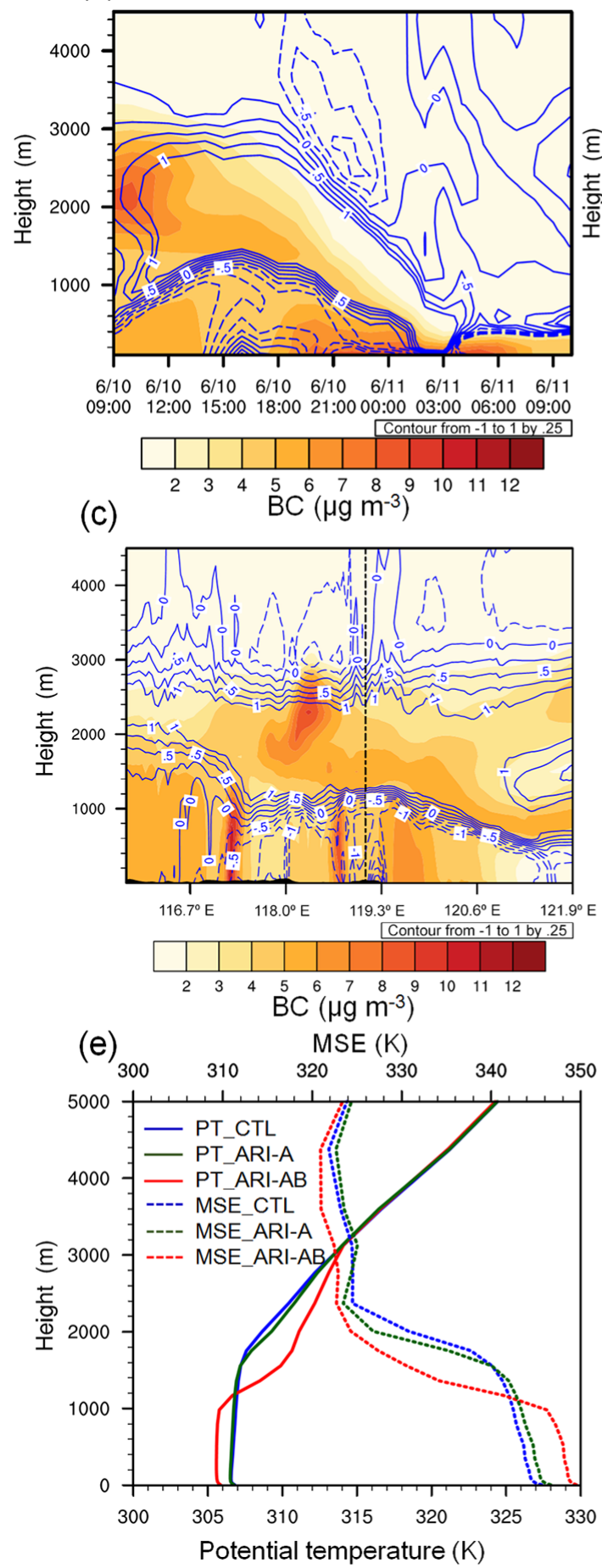

(b)
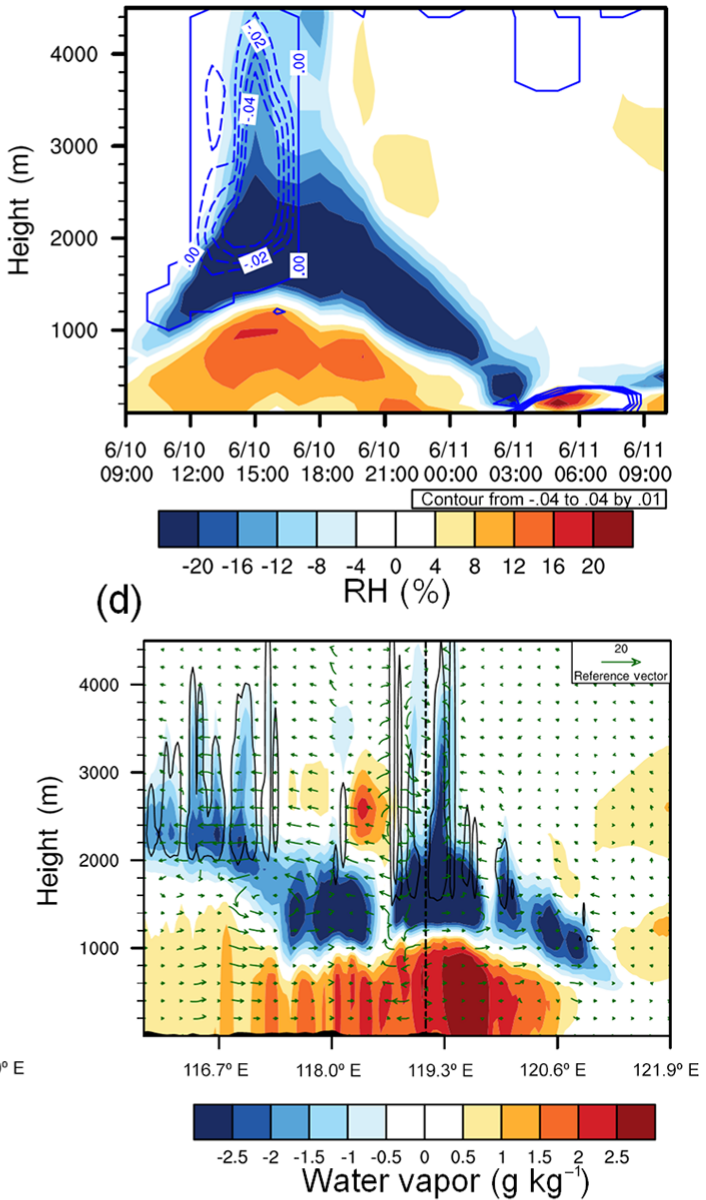

(f)

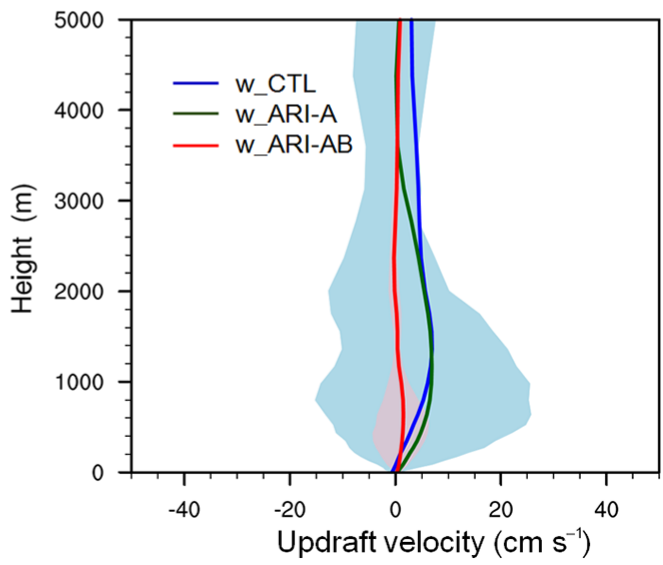

Figure 10. (a) Temporal evolutions of BC vertical profile and changes in air temperature (K); (b) perturbations in RH (\%) and cloud water $\left(\mathrm{g} \mathrm{kg}^{1}\right)$ over Zone 1. (c) Longitude-height cross sections of BC concentrations and aerosol-induced temperature changes at 14:00 LT, 10 June. (d) Same as (c) but for water vapor $\left(\mathrm{g} \mathrm{kg}^{1}\right)$ and wind fields $\left(\mathrm{m} \mathrm{s}^{-1}\right)$. Note that the vertical wind speed was multiplied by a factor of 100 . Red and black lines in (d) outline cloud coverage (cloud water mass ratio greater than $10^{-3} \mathrm{~g} \mathrm{~kg}^{1}$ ) in ARI-AB and CTL simulations. In this case, the condensate mass ratio was less than $10^{-3} \mathrm{~g} \mathrm{~kg}^{1}$ for the whole column in ARI-AB; thus no red line is presented in Fig. 10d. (e) Vertical profile of zone-averaged potential temperature (PT) and MSE and (f) updraft velocity predicted by CTL (blue), ARI-A (green) and ARI-AB (red) at 14:00 LT. Shadows in Fig. 10f represent 25-75th percentile range of simulated updraft velocity. 
(a)
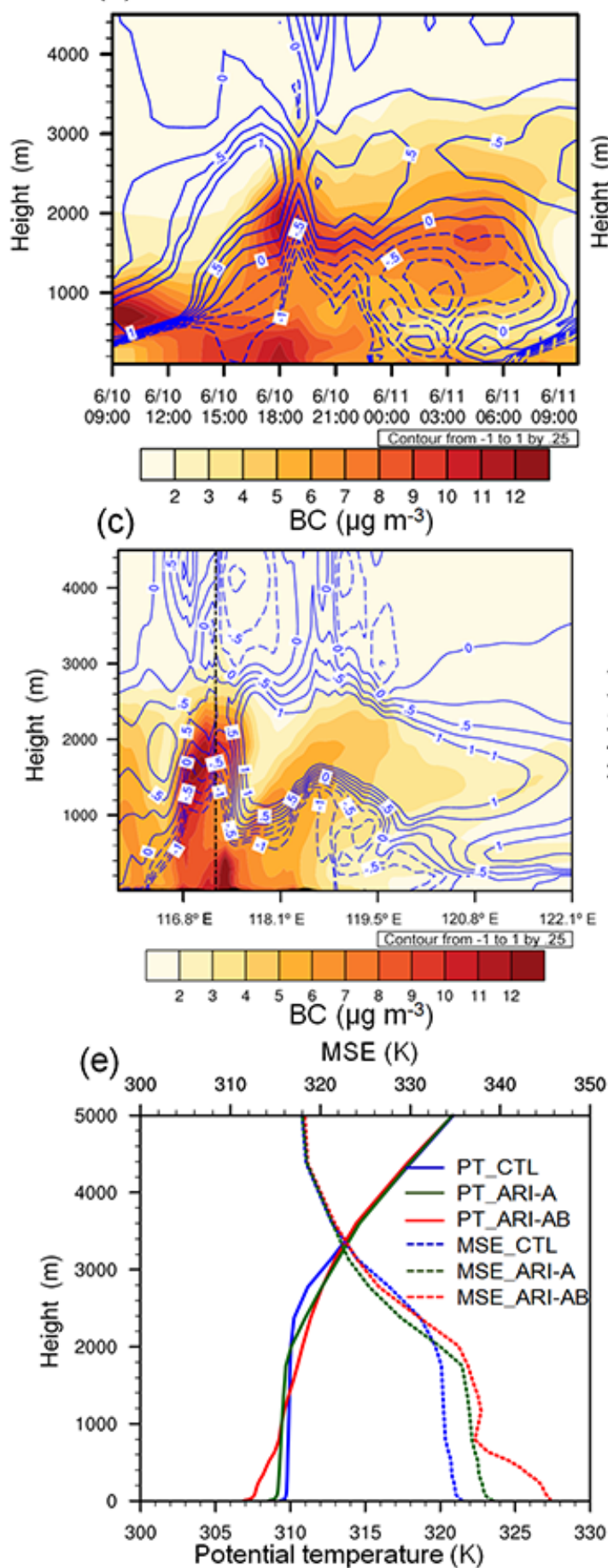

(b)
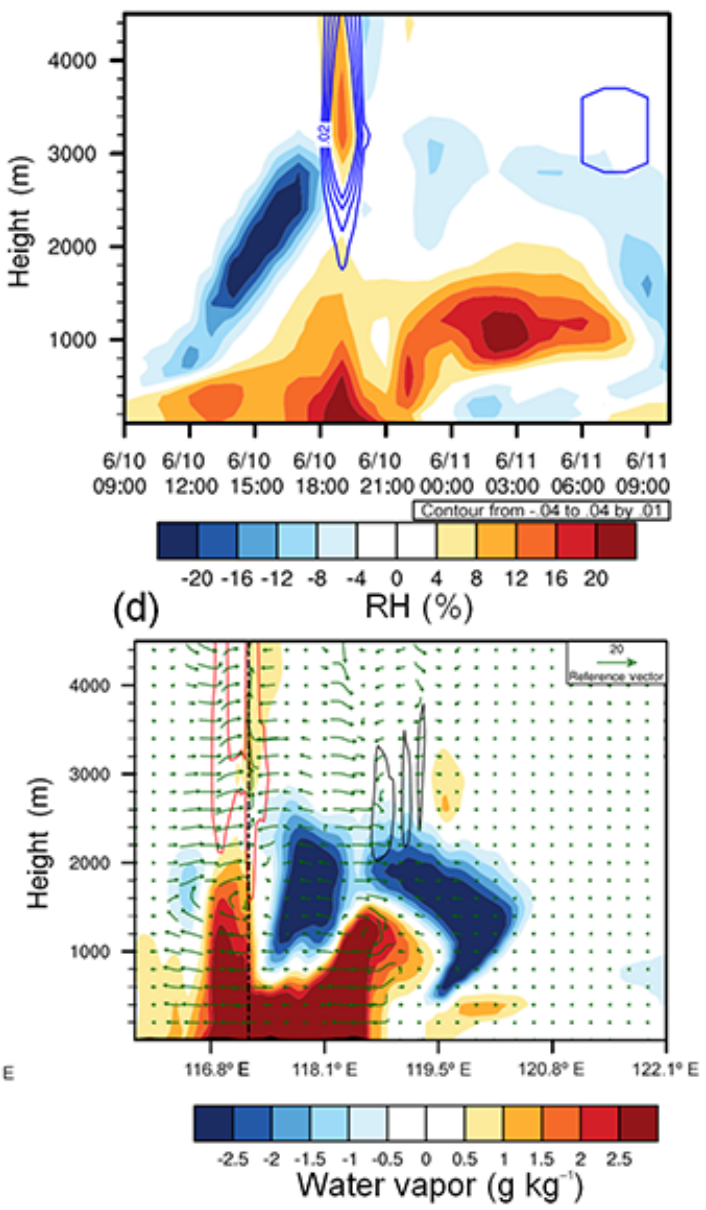

(f)

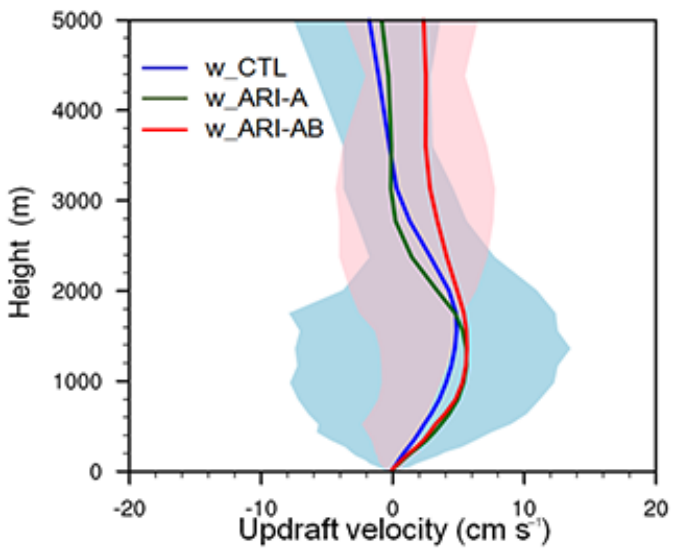

Figure 11. (a) Temporal evolutions of BC vertical profile and changes in air temperature (K); (b) perturbations in RH (\%) and cloud water $\left(\mathrm{g} \mathrm{kg}^{1}\right.$ ) over Zone 2. (c) Longitude-height cross sections of BC concentrations and aerosol-induced temperature changes at 18:00 LT, 10 June. (d) Same as (c) but for water vapor $\left(\mathrm{g} \mathrm{kg}^{1}\right)$ and wind fields $\left(\mathrm{m} \mathrm{s}^{-1}\right)$. Note that the vertical wind speed was multiplied by a factor of 100 . Red and black lines in (d) outline cloud coverage (cloud water mass ratio greater than $10^{-3} \mathrm{~g} \mathrm{~kg}^{1}$ ) in ARI-AB and CTL simulations. (e) Vertical profile of zone-averaged potential temperature (PT) and MSE and (f) updraft velocity predicted by CTL (blue), ARI-A (green) and ARI-AB (red) at 18:00 LT. Shadows in $\mathrm{f}$ represent $25-75$ th percentile range of simulated updraft velocity. 
(a)
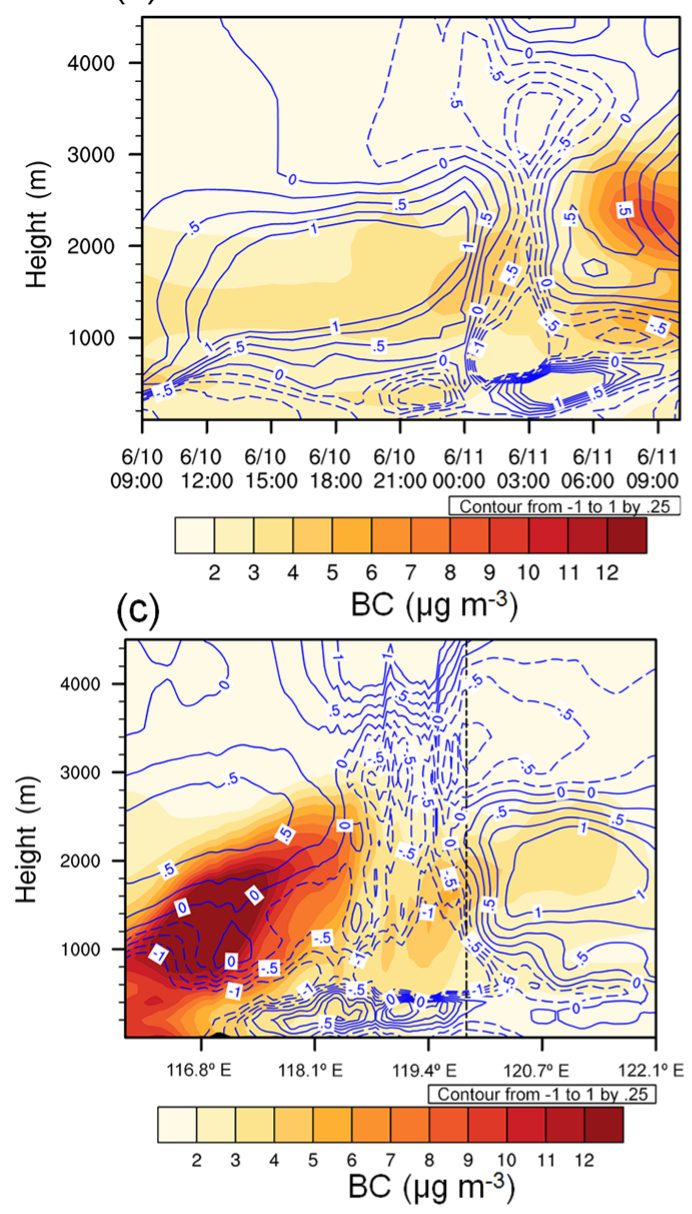

MSE (K)

(e)

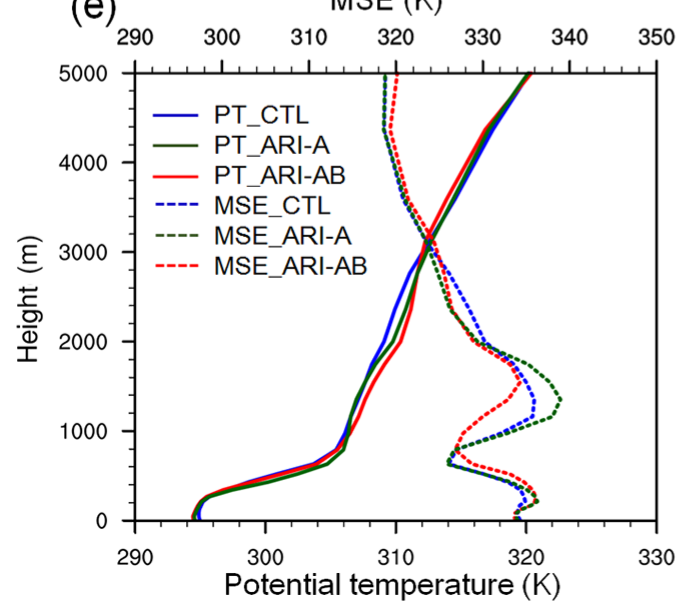

(b)
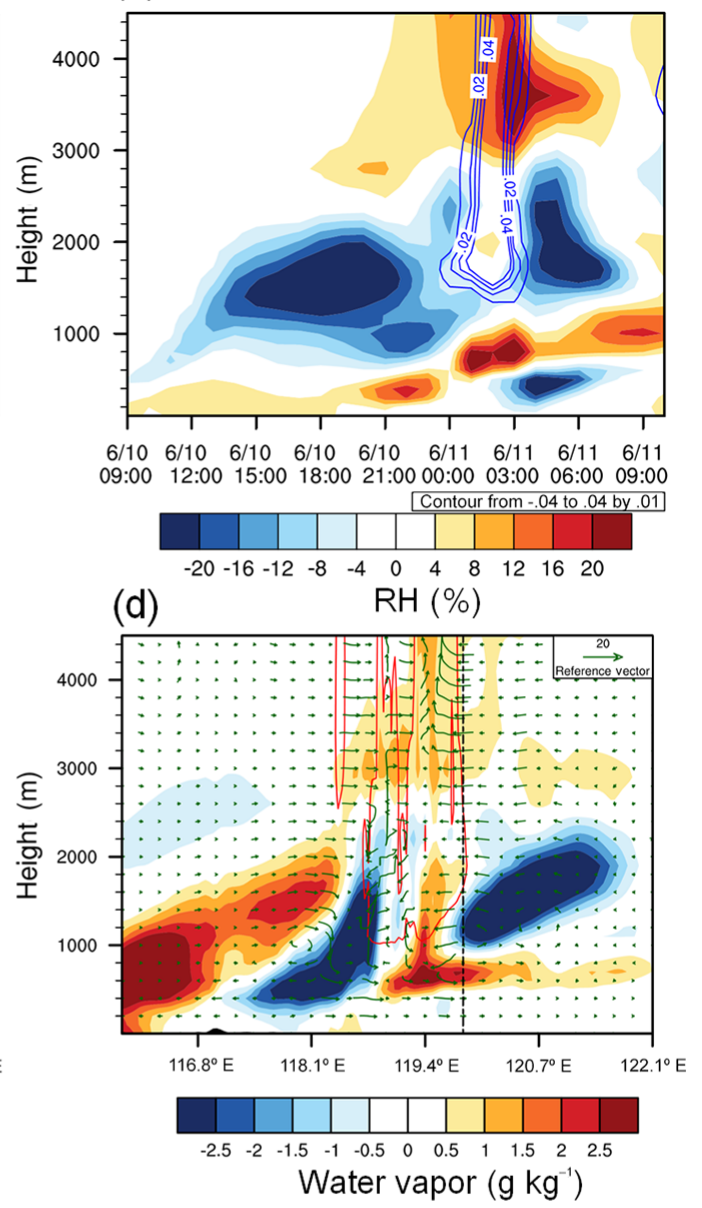

(f)

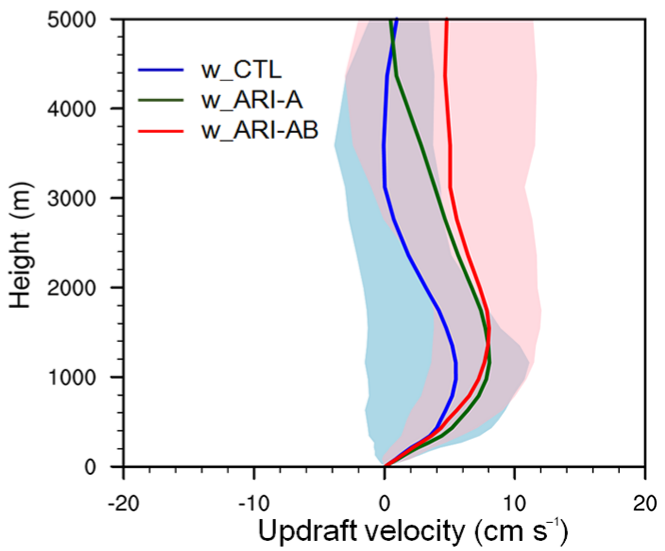

Figure 12. (a) Temporal evolutions of BC vertical profile and changes in air temperature (K); (b) perturbations in RH (\%) and cloud water $\left(\mathrm{g} \mathrm{kg}^{1}\right.$ ) over Zone 3. (c) Longitude-height cross sections of BC concentrations and aerosol-induced temperature changes at 01:00 LT, 11 June. (d) Same as (c) but for water vapor $\left(\mathrm{g} \mathrm{kg}^{1}\right)$ and wind fields $\left(\mathrm{m} \mathrm{s}^{-1}\right)$. Note that the vertical wind speed was multiplied by a factor of 100 . Red and black lines in (d) outline cloud coverage (cloud water mass ratio greater than $10^{-3} \mathrm{~g} \mathrm{~kg}^{1}$ ) in ARI-AB and CTL simulations. In this case, the condensate mass ratio was less than $10^{-3} \mathrm{~g} \mathrm{~kg}^{1}$ for the whole column in CTL, thus no black line is presented in Fig.12d. (e) Vertical profile of zone-averaged potential temperature (PT) and MSE and (f) updraft velocity predicted by CTL (blue), ARI-A (green) and ARI-AB (red) at 01:00 LT. Shadows in Fig. 12f represent 25-75th percentile range of simulated updraft velocity. 
masses originating from the ocean brought in excess water vapor and consequently elevated the humidity above $3 \mathrm{~km}$. More MSE accumulated above $3 \mathrm{~km}$ in the ARI-AB experiment compared with that simulated by the CTL and ARI-A experiments before the precipitation also support this view (Fig. 12e). We suggest that these precipitating clouds formed because of instability at the top of the smoke layer, driven by the strong radiation absorption that warmed the surrounding air. Therefore, the heated BC-laden air was ascended and cooled, leading to the formation of clouds preferentially in the conditionally unstable zone in the upper air.

\subsection{Uncertainties}

Though the modeling work here characterized cloud and precipitation anomalies during the biomass-burning event, we may also question to what extent the modeling reproduced the relevant processes in the real world. As widely acknowledged, accurate simulation of smoke plume and prediction of clouds are both challenging for regional/global models. One contributor to the uncertainties is the quantification of fire emission. The magnitude was determined by statistical information and laboratory experiment data, the accuracy and representativeness of which may introduce some uncertainties. The spatiotemporal distribution of fire emission was allocated based on MODIS retrievals. Loss of information due to cloud coverage and poor detection efficiency of shortlived or small-scale fires are major limitations (Giglio et al., 2003). Another challenge is quantification of heat release from biomass burning and subsequent effects on local and regional meteorology. Furthermore, much attention has been paid to the vertical distribution of absorbing aerosol, to which the cloud response is highly sensitive (Koch and Del Genio, 2010). The vertical profile of absorbing aerosol in this simulation underwent little constrain due to limited observation at that time. The regional model is hardly capable of precisely presenting turbulent flows and vertical transport, thus introducing uncertainties in three dimensional distributions of BC. It also should be noted that BC is co-emitted with other components such as OC and sulfur dioxide that oxidize to sulfate (Xie et al., 2015). Mixing with other scattering aerosol would considerably amplify the absorbing efficiency of BC. A model's ability to account for the evolution of mixing state and how to quantify its amplification also affect the simulated radiative behaviors. Besides, poorly recognized secondary organic carbon formation processes and its light absorption make it imperative to reassess and redefine the chemical mechanism and optical properties of OC in models (Saleh et al., 2014). The large uncertainty in simulating clouds and further aerosol-cloud interaction is another limitation (e.g., Wang et al., 2011; Tao et al., 2012). To improve the model performance in all these chemical and physical processes, more comprehensive measurements and modeling efforts are needed in the future.

\section{Conclusions}

To investigate radiative effects of aerosol-radiation interaction on cloud and precipitation modifications during the exceptionally active agricultural fire season in June 2012, a bottom-up emission inventory of crop open burning was developed and then the fully coupled online WRF-Chem model was applied in this work. The evaluation of simulation through ground-based observations and satellite retrievals showed that the model generally captured spatial patterns and temporal variations of fire pollution, which was predominantly concentrating over northern Anhui and centralnorthern Jiangsu. It is evident that post-harvest burning of crop residues emitted a tremendous amount of atmospheric pollutants and deteriorated regional air quality to a large extent in East China. Elevated concentration of aerosols, particularly light-absorbing $\mathrm{BC}$, would heat the atmosphere and cool the ground surface through both direct solar radiation attenuation (direct radiative forcing) and cloud redistribution (semi-direct radiative forcing). These radiative cooling (heating) effects were distinct close to (downwind from) the source regions of fire sites. Adjusted temperature stratification was intimately linked to small-scale processes such as turbulent mixing, entrainment and the evolution of the boundary layer. Subsequently, over Nanjing and its adjacent regions, absorbing aerosols immediately above the boundary layer top increased the inversion beneath, reducing available moisture and leading to a burn-off effect of cloud. Meanwhile, fire plumes played an enhancement role in nocturnal precipitation over northern Jiangsu by increasing up-level convective activity and fostering low-level convergence that carries in more moist air. Overall, aerosols' radiative effect on precipitation modification is therefore likely to depend to a large extent on local meteorological conditions like atmospheric instability and humidity.

\section{Data availability}

Meteorological datasets used in this work can be acquired from http://rda.ucar.edu/datasets/ds463.3/ and http://weather. uwyo.edu/upperair/sounding.html. Model outputs and radiation observations are available on request from the corresponding author.

\section{The Supplement related to this article is available online at doi:10.5194/acp-16-10063-2016-supplement.}

Acknowledgements. This work was supported by the National Natural Science Foundation of China (D0512/91544231, D0512/41422504 and D0510/41505109). Part of this work was supported by the Jiangsu Provincial Science Fund for Distinguished Young Scholars awarded to Aijun Ding (no. BK20140021). 
Edited by: V.-M. Kerminen

Reviewed by: two anonymous referees

\section{References}

Akagi, S. K., Yokelson, R. J., Wiedinmyer, C., Alvarado, M. J., Reid, J. S., Karl, T., Crounse, J. D., and Wennberg, P. O.: Emission factors for open and domestic biomass burning for use in atmospheric models, Atmos. Chem. Phys., 11, 4039-4072, doi:10.5194/acp-11-4039-2011, 2011.

Andreae, M. O. and Merlet, P.: Emission of trace gases and aerosols from biomass burning, Global Biogeochem. Cy., 15, 955-966, doi:10.1029/2000gb001382, 2001.

Andreae, M. O., Browell, E. V., Garstang, M., Gregory, G. L., Harriss, R. C., Hill, G. F., Jacob, D. J., Pereira, M. C., Sachse, G. W., Setzer, A. W., Dias, P. L. S., Talbot, R. W., Torres, A. L., and Wofsy, S. C.: Biomass-Burning Emissions and Associated Haze Layers over Amazonia, J. Geophys. Res.-Atmos., 93, 1509-1527, doi:10.1029/Jd093id02p01509, 1988.

Andreae, M. O., Rosenfeld, D., Artaxo, P., Costa, A. A., Frank, G. P., Longo, K. M., and Silva-Dias, M. A. F.: Smoking rain clouds over the Amazon, Science, 303, 1337-1342, doi:10.1126/science.1092779, 2004.

Barnard, J. C., Fast, J. D., Paredes-Miranda, G., Arnott, W. P., and Laskin, A.: Technical Note: Evaluation of the WRF-Chem "Aerosol Chemical to Aerosol Optical Properties" Module using data from the MILAGRO campaign, Atmos. Chem. Phys., 10, 7325-7340, doi:10.5194/acp-10-7325-2010, 2010.

Bergamaschi, P., Hein, R., Heimann, M., and Crutzen, P. J.: Inverse modeling of the global $\mathrm{CO}$ cycle 1 . Inversion of CO mixing ratios, J. Geophys. Res.-Atmos., 105, 1909-1927, doi:10.1029/1999jd900818, 2000.

Berge, E., Huang, H. C., Chang, J., and Liu, T. H.: A study of the importance of initial conditions for photochemical oxidant modeling, J. Geophys. Res.-Atmos., 106, 1347-1363, doi:10.1029/2000jd900227, 2001.

Bond, T. C., Doherty, S. J., Fahey, D. W., Forster, P. M., Berntsen, T., DeAngelo, B. J., Flanner, M. G., Ghan, S., Karcher, B., Koch, D., Kinne, S., Kondo, Y., Quinn, P. K., Sarofim, M. C., Schultz, M. G., Schulz, M., Venkataraman, C., Zhang, H., Zhang, S., Bellouin, N., Guttikunda, S. K., Hopke, P. K., Jacobson, M. Z., Kaiser, J. W., Klimont, Z., Lohmann, U., Schwarz, J. P., Shindell, D., Storelvmo, T., Warren, S. G., and Zender, C. S.: Bounding the role of black carbon in the climate system: A scientific assessment, J. Geophys. Res.-Atmos., 118, 5380-5552, doi:10.1002/jgrd.50171, 2013.

Boschetti, L., Roy, D., and Hoffmann, A.: MODIS Collection 5 Burned Area Product-MCD45, User's Guide, Version, 2, 2009.

Capes, G., Johnson, B., McFiggans, G., Williams, P., Haywood, J., and Coe, H.: Aging of biomass burning aerosols over West Africa: Aircraft measurements of chemical composition, microphysical properties, and emission ratios, J. Geophys. Res.Atmos., 113, D00C15, doi:10.1029/2008JD009845, 2008.

Chi, X., Winderlich, J., Mayer, J.-C., Panov, A. V., Heimann, M., Birmili, W., Heintzenberg, J., Cheng, Y., and Andreae, M. O.: Long-term measurements of aerosol and carbon monoxide at the ZOTTO tall tower to characterize polluted and pristine air in the Siberian taiga, Atmos. Chem. Phys., 13, 12271-12298, doi:10.5194/acp-13-12271-2013, 2013.

Crutzen, P. J. and Andreae, M. O.: Biomass Burning in the Tropics Impact on Atmospheric Chemistry and Biogeochemical Cycles, Science, 250, 1669-1678, doi:10.1126/science.250.4988.1669, 1990.

Ding, A. J., Fu, C. B., Yang, X. Q., Sun, J. N., Petäjä, T., Kerminen, V.-M., Wang, T., Xie, Y., Herrmann, E., Zheng, L. F., Nie, W., Liu, Q., Wei, X. L., and Kulmala, M.: Intense atmospheric pollution modifies weather: a case of mixed biomass burning with fossil fuel combustion pollution in eastern China, Atmos. Chem. Phys., 13, 10545-10554, doi:10.5194/acp-1310545-2013, 2013a.

Ding, A. J., Fu, C. B., Yang, X. Q., Sun, J. N., Zheng, L. F., Xie, Y. N., Herrmann, E., Nie, W., Petäjä, T., Kerminen, V.-M., and Kulmala, M.: Ozone and fine particle in the western Yangtze River Delta: an overview of $1 \mathrm{yr}$ data at the SORPES station, Atmos. Chem. Phys., 13, 5813-5830, doi:10.5194/acp-13-58132013, 2013b.

Ding, A. J., Huang, X., Nie, W., Sun, J. N., Kerminen, V. M., Petäjä, T., Su, H., Cheng, Y. F., Yang, X. Q., Wang, M. H., Chi, X. G., Wang, J. P., Virkkula, A., Guo, W. D., Yuan, J., Wang, S. Y., Zhang, R. J., Wu, Y. F., Song, Y., Zhu, T., Zilitinkevich, S., Kulmala, M., and Fu, C. B.: Enhanced haze polltuion by black carbon in megacities in China, Geophys. Res. Lett., 43, 2873-2879, doi:10.1002/2016GL067745, 2016.

Draxler, R. R. and Rolph, G.: HYSPLIT (HYbrid Single-Particle Lagrangian Integrated Trajectory) model access via NOAA ARL READY website, http://www.arl.noaa.gov/ready/hysplit4. html (last access: 2 July 2016), NOAA Air Resources Laboratory, Silver Spring, Md, 2003.

Ek, M. B., Mitchell, K. E., Lin, Y., Rogers, E., Grunmann, P., Koren, V., Gayno, G., and Tarpley, J. D.: Implementation of Noah land surface model advances in the National Centers for Environmental Prediction operational mesoscale Eta model, J. Geophys. Res.-Atmos., 108, 8851, doi:10.1029/2002jd003296, 2003.

Fan, J. W., Rosenfeld, D., Yang, Y., Zhao, C., Leung, L. R., and Li, Z. Q.: Substantial contribution of anthropogenic air pollution to catastrophic floods in Southwest China, Geophys. Res. Lett., 42, 6066-6075, doi:10.1002/2015GL064479, 2015.

Fast, J. D., Gustafson, W. I., Easter, R. C., Zaveri, R. A., Barnard, J. C., Chapman, E. G., Grell, G. A., and Peckham, S. E.: Evolution of ozone, particulates, and aerosol direct radiative forcing in the vicinity of Houston using a fully coupled meteorology-chemistry-aerosol model, J. Geophys. Res.-Atmos., 111, D21305, doi:10.1029/2005jd006721, 2006.

Fearnside, P. M.: Global warming and tropical land-use change: greenhouse gas emissions from biomass burning, decomposition and soils in forest conversion, shifting cultivation and secondary vegetation, Climatic change, 46, 115-158, 2000.

Feingold, G., Jiang, H. L., and Harrington, J. Y.: On smoke suppression of clouds in Amazonia, Geophys. Res. Lett., 32, L02804, doi:10.1029/2004gl021369, 2005.

Gao, M., Carmichael, G. R., Wang, Y., Saide, P. E., Yu, M., Xin, J., Liu, Z., and Wang, Z.: Modeling study of the 2010 regional haze event in the North China Plain, Atmos. Chem. Phys., 16, 1673-1691, doi:10.5194/acp-16-1673-2016, 2016. 
Gao, X., Ma, W., Ma, C., Zhang, F., and Wang, Y.: Analysis on the current status of utilization of crop straw in China (in Chinese), Journal of Huazhong Agricultural University, 21, 242-247, 2002.

Giglio, L., Descloitres, J., Justice, C. O., and Kaufman, Y. J.: An enhanced contextual fire detection algorithm for MODIS, Remote. Sens. Environ., 87, 273-282, doi:10.1016/S00344257(03)00184-6, 2003.

Grell, G., Freitas, S. R., Stuefer, M., and Fast, J.: Inclusion of biomass burning in WRF-Chem: impact of wildfires on weather forecasts, Atmos. Chem. Phys., 11, 5289-5303, doi:10.5194/acp11-5289-2011, 2011.

Grell, G. A. and Devenyi, D.: A generalized approach to parameterizing convection combining ensemble and data assimilation techniques, Geophys. Res. Lett., 29, 1693, doi:10.1029/2002g1015311, 2002.

Guenther, A., Karl, T., Harley, P., Wiedinmyer, C., Palmer, P. I., and Geron, C.: Estimates of global terrestrial isoprene emissions using MEGAN (Model of Emissions of Gases and Aerosols from Nature), Atmos. Chem. Phys., 6, 3181-3210, doi:10.5194/acp-63181-2006, 2006.

Hong, S. Y.: A new stable boundary-layer mixing scheme and its impact on the simulated East Asian summer monsoon, Q. J. Roy. Meteor. Soc., 136, 1481-1496, doi:10.1002/Qj.665, 2010.

Hsu, Y., Strait, R., Roe, S., and Holoman, D. S.: 4.0. Speciation Database Development Documentation. Final Report. EPA contract. Nos, EP-D-06.001, work assignment Numbers 0-03 and 68-D-02-063, WA 4-04 and WA 5-05. EPA/600/R06/16, http://www.epa.gov/ttn/chief/software/speciate/speciate4/ documentation/speciatedoc_1206.pdf (last access: 2 July 2016), 2006.

Huang, X., Song, Y., Li, M., Li, J., Huo, Q., Cai, X., Zhu, T., Hu, M., and Zhang, H.: A high-ammonia emission inventory in China, Global Biogeochem. Cy., 26, GB1030, doi:10.1029/2011GB004161, 2012a.

Huang, X., Li, M. M., Li, J. F., and Song, Y.: A high-resolution emission inventory of crop burning in fields in China based on MODIS Thermal Anomalies/Fire products, Atmos. Environ., 50, 9-15, doi:10.1016/j.atmosenv.2012.01.017, 2012b.

Huang, X., Song, Y., Li, M. M., Li, J. F., and Zhu, T.: Harvest season, high polluted season in East China, Environ. Res. Lett., 7, 044033, doi:10.1088/1748-9326/7/4/044033, 2012c.

Huang, X., Song, Y., Zhao, C., Cai, X. H., Zhang, H. S., and Zhu, T.: Direct Radiative Effect by Multicomponent Aerosol over China, J. Climate, 28, 3472-3495, doi:10.1175/Jcli-D-14$00365.1,2015$.

Ito, A., Ito, A., and Akimoto, H.: Seasonal and interannual variations in $\mathrm{CO}$ and $\mathrm{BC}$ emissions from open biomass burning in Southern Africa during 1998-2005, Global Biogeochem. Cy., 21, Gb2011, doi:10.1029/2006gb002848, 2007.

Jacobson, M. Z.: Control of fossil-fuel particulate black carbon and organic matter, possibly the most effective method of slowing global warming, J. Geophys. Res.-Atmos., 107, 4410, doi:10.1029/2001jd001376, 2002.

Koch, D. and Del Genio, A. D.: Black carbon semi-direct effects on cloud cover: review and synthesis, Atmos. Chem. Phys., 10, 7685-7696, doi:10.5194/acp-10-7685-2010, 2010.

Kolusu, S. R., Marsham, J. H., Mulcahy, J., Johnson, B., Dunning, C., Bush, M., and Spracklen, D. V.: Impacts of Amazonia biomass burning aerosols assessed from short-range weather forecasts, Atmos. Chem. Phys., 15, 12251-12266, doi:10.5194/acp-15-12251-2015, 2015.

Koren, I., Kaufman, Y. J., Remer, L. A., and Martins, J. V.: Measurement of the effect of Amazon smoke on inhibition of cloud formation, Science, 303, 1342-1345, doi:10.1126/science.1089424, 2004.

Krishnan, R. and Ramanathan, V.: Evidence of surface cooling from absorbing aerosols, Geophys. Res. Lett., 29, 1340, doi:10.1029/2002gl014687, 2002.

Kuhlbusch, T. A. J.: Black carbon and the carbon cycle, Science, 280, 1903-1904, doi:10.1126/science.280.5371.1903, 1998.

Kulmala, M., Lappalainen, H. K., Petäjä, T., Kurten, T., Kerminen, V.-M., Viisanen, Y., Hari, P., Sorvari, S., Bäck, J., Bondur, V., Kasimov, N., Kotlyakov, V., Matvienko, G., Baklanov, A., Guo, H. D., Ding, A., Hansson, H.-C., and Zilitinkevich, S.: Introduction: The Pan-Eurasian Experiment (PEEX) multidisciplinary, multiscale and multicomponent research and capacity-building initiative, Atmos. Chem. Phys., 15, 1308513096, doi:10.5194/acp-15-13085-2015, 2015.

Langenfelds, R. L., Francey, R. J., Pak, B. C., Steele, L. P., Lloyd, J., Trudinger, C. M., and Allison, C. E.: Interannual growth rate variations of atmospheric $\mathrm{CO}_{2}$ and its $\delta^{13} \mathrm{C}, \mathrm{H}_{2}, \mathrm{CH}_{4}$, and $\mathrm{CO}$ between 1992 and 1999 linked to biomass burning, Global Biogeochem. Cy., 16, 1048, doi:10.1029/2001gb001466, 2002.

Lappalainen, H. K., Kerminen, V.-M., Petäjä, T., Kurten, T., Baklanov, A., Shvidenko, A., Bäck, J., Vihma, T., Alekseychik, P., Arnold, S., Arshinov, M., Asmi, E., Belan, B., Bobylev, L., Chalov, S., Cheng, Y., Chubarova, N., de Leeuw, G., Ding, A., Dobrolyubov, S., Dubtsov, S., Dyukarev, E., Elansky, N., Eleftheriadis, K., Esau, I., Filatov, N., Flint, M., Fu, C., Glezer, O., Gliko, A., Heimann, M., Holtslag, A. A. M., Hõrrak, U., Janhunen, J., Juhola, S., Järvi, L., Järvinen, H., Kanukhina, A., Konstantinov, P., Kotlyakov, V., Kieloaho, A.-J., Komarov, A. S., Kujansuu, J., Kukkonen, I., Kyrö, E., Laaksonen, A., Laurila, T., Lihavainen, H., Lisitzin, A., Mahura, A., Makshtas, A., Mareev, E., Mazon, S., Matishov, D., Melnikov, V., Mikhailov, E., Moisseev, D., Nigmatulin, R., Noe, S. M., Ojala, A., Pihlatie, M., Popovicheva, O., Pumpanen, J., Regerand, T., Repina, I., Shcherbinin, A., Shevchenko, V., Sipilä, M., Skorokhod, A., Spracklen, D. V., Su, H., Subetto, D. A., Sun, J., Terzhevik, A. Y., Timofeyev, Y., Troitskaya, Y., Tynkkynen, V.-P., Kharuk, V. I., Zaytseva, N., Zhang, J., Viisanen, Y., Vesala, T., Hari, P., Hansson, H. C., Matvienko, G. G., Kasimov, N. S., Guo, H., Bondur, V., Zilitinkevich, S., and Kulmala, M.: Pan-Eurasian Experiment (PEEX): Towards holistic understanding of the feedbacks and interactions in the land-atmosphere-ocean-society continuum in the Northern Eurasian region, Atmos. Chem. Phys. Discuss., doi:10.5194/acp-2016-186, in review, 2016.

Lau, K. M., Kim, M. K., and Kim, K. M.: Asian summer monsoon anomalies induced by aerosol direct forcing: the role of the Tibetan Plateau, Clim. Dynam., 26, 855-864, doi:10.1007/s00382006-0114-z, 2006.

Li, J. F., Song, Y., Mao, Y., Mao, Z. C., Wu, Y. S., Li, M. M., Huang, X., He, Q. C., and Hu, M.: Chemical characteristics and source apportionment of $\mathrm{PM}_{2.5}$ during the harvest season in eastern China's agricultural regions, Atmos. Environ., 92, 442-448, doi:10.1016/j.atmosenv.2014.04.058, 2014.

Li, M., Zhang, Q., Kurokawa, J., Woo, J.-H., He, K. B., Lu, Z., Ohara, T., Song, Y., Streets, D. G., Carmichael, G. R., Cheng, Y. 
F., Hong, C. P., Huo, H., Jiang, X. J., Kang, S. C., Liu, F., Su, H., and Zheng, B.: MIX: a mosaic Asian anthropogenic emission inventory for the MICS-Asia and the HTAP projects, Atmos. Chem. Phys. Discuss., 15, 34813-34869, doi:10.5194/acpd-1534813-2015, 2015.

Lin, Y. L., Farley, R. D., and Orville, H. D.: Bulk Parameterization of the Snow Field in a Cloud Model, J. Clim. Appl. Meteorol., 22, 1065-1092, doi:10.1175/15200450(1983)022<1065:Bpotsf>2.0.Co;2, 1983.

Liu, Y., Fu, R., and Dickinson, R.: Smoke aerosols altering South American monsoon, B. Am. Meteorol. Soc., 86, 1062-1063, 2005.

Lo, J. C. F., Yang, Z. L., and Pielke, R. A.: Assessment of three dynamical climate downscaling methods using the Weather Research and Forecasting (WRF) model, J. Geophys. Res.-Atmos., 113, D09112, doi:10.1029/2007jd009216, 2008.

Menon, S., Hansen, J., Nazarenko, L., and Luo, Y. F.: Climate effects of black carbon aerosols in China and India, Science, 297, 2250-2253, doi:10.1126/science.1075159, 2002.

Mlawer, E. J., Taubman, S. J., Brown, P. D., Iacono, M. J., and Clough, S. A.: Radiative transfer for inhomogeneous atmospheres: RRTM, a validated correlated-k model for the longwave, J. Geophys. Res.-Atmos., 102, 16663-16682, doi:10.1029/97jd00237, 1997.

NBSC: China Statistical Yearbook National Bureau of Statistics of China ed., China Statistics Press, Beijing, 2013.

Nie, W., Ding, A. J., Xie, Y. N., Xu, Z., Mao, H., Kerminen, V.M., Zheng, L. F., Qi, X. M., Huang, X., Yang, X.-Q., Sun, J. N., Herrmann, E., Petäjä, T., Kulmala, M., and Fu, C. B.: Influence of biomass burning plumes on HONO chemistry in eastern China, Atmos. Chem. Phys., 15, 1147-1159, doi:10.5194/acp-15-11472015, 2015.

Penner, J. E., Dickinson, R. E., and Oneill, C. A.: Effects of Aerosol from Biomass Burning on the Global Radiation Budget, Science, 256, 1432-1434, doi:10.1126/science.256.5062.1432, 1992.

Procopio, A. S., Artaxo, P., Kaufman, Y. J., Remer, L. A., Schafer, J. S., and Holben, B. N.: Multiyear analysis of amazonian biomass burning smoke radiative forcing of climate, Geophys. Res. Lett., 31, L03108, doi:10.1029/2003g1018646, 2004.

Ramanathan, V. and Carmichael, G.: Global and regional climate changes due to black carbon, Nat. Geosci., 1, 221-227, doi:10.1038/ngeo156, 2008.

Ramanathan, V., Chung, C., Kim, D., Bettge, T., Buja, L., Kiehl, J. T., Washington, W. M., Fu, Q., Sikka, D. R., and Wild, M.: Atmospheric brown clouds: Impacts on South Asian climate and hydrological cycle, P. Natl. Acad. Sci. USA, 102, 5326-5333, doi:10.1073/pnas.0500656102, 2005.

Reid, J. S., Hobbs, P. V., Liousse, C., Martins, J. V., Weiss, R. E., and Eck, T. F.: Comparisons of techniques for measuring shortwave absorption and black carbon content of aerosols from biomass burning in Brazil, J. Geophys. Res.-Atmos., 103, 32031-32040, doi:10.1029/98jd00773, 1998.

Reid, J. S., Koppmann, R., Eck, T. F., and Eleuterio, D. P.: A review of biomass burning emissions part II: intensive physical properties of biomass burning particles, Atmos. Chem. Phys., 5, 799825, doi:10.5194/acp-5-799-2005, 2005.

Robock, A.: Enhancement of Surface Cooling Due to Forest Fire Smoke, Science, 242, 911-913, 1988.
Robock, A.: Surface Cooling Due to Forest-Fire Smoke, J. Geophys. Res.-Atmos., 96, 20869-20878, doi:10.1029/91jd02043, 1991.

Rosenfeld, D.: TRMM observed first direct evidence of smoke from forest fires inhibiting rainfall, Geophys. Res. Lett., 26, 3105 3108, doi:10.1029/1999gl006066, 1999.

Rosenfeld, D., Lohmann, U., Raga, G. B., O’Dowd, C. D., Kulmala, M., Fuzzi, S., Reissell, A., and Andreae, M. O.: Flood or drought: How do aerosols affect precipitation?, Science, 321, 1309-1313, doi:10.1126/science.1160606, 2008.

Roy, D. P. and Boschetti, L.: Southern Africa Validation of the MODIS, L3JRC, and GlobCarbon BurnedArea Products, IEEE T. Geosci. Remote, 47, 1032-1044, doi:10.1109/Tgrs.2008.2009000, 2009.

Ryu, S. Y., Kwon, B. G., Kim, Y. J., Kim, H. H., and Chun, K. J.: Characteristics of biomass burning aerosol and its impact on regional air quality in the summer of 2003 at Gwangju, Korea, Atmos. Res., 84, 362-373, doi:10.1016/j.atmosres.2006.09.007, 2007.

Sakaeda, N., Wood, R., and Rasch, P. J.: Direct and semidirect aerosol effects of southern African biomass burning aerosol, J. Geophys. Res.-Atmos., 116, D12205, doi:10.1029/2010jd015540, 2011.

Saleh, R., Robinson, E. S., Tkacik, D. S., Ahern, A. T., Liu, S., Aiken, A. C., Sullivan, R. C., Presto, A. A., Dubey, M. K., Yokelson, R. J., Donahue, N. M., and Robinson, A. L.: Brownness of organics in aerosols from biomass burning linked to their black carbon content, Nat. Geosci., 7, 647-650, doi:10.1038/NGEO2220, 2014.

Schwarz, J. P., Gao, R. S., Spackman, J. R., Watts, L. A., Thomson, D. S., Fahey, D. W., Ryerson, T. B., Peischl, J., Holloway, J. S., Trainer, M., Frost, G. J., Baynard, T., Lack, D. A., de Gouw, J. A., Warneke, C., and Del Negro, L. A.: Measurement of the mixing state, mass, and optical size of individual black carbon particles in urban and biomass burning emissions, Geophys. Res. Lett., 35, L13810, doi:10.1029/2008g1033968, 2008.

Simpson, J., Adler, R. F., and North, G. R.: A Proposed Tropical Rainfall Measuring Mission (Trmm) Satellite, B. Am. Meteorol. Soc., 69, 278-295, doi:10.1175/15200477(1988)069<0278:Aptrmm>2.0.Co;2, 1988.

Tao, W. K., J. P. Chen, Z. Q. Li, C. Wang, and C. D. Zhang, Impact of Aerosols on Convective Clouds and Precipitation, Rev. Geophys., 50, RG2001, doi:10.1029/2011rg000369, 2012.

van der Werf, G. R., Randerson, J. T., Giglio, L., Collatz, G. J., Kasibhatla, P. S., and Arellano Jr., A. F.: Interannual variability in global biomass burning emissions from 1997 to 2004, Atmos. Chem. Phys., 6, 3423-3441, doi:10.5194/acp-6-3423-2006, 2006.

Wang, M., Ghan, S., Ovchinnikov, M., Liu, X., Easter, R., Kassianov, E., Qian, Y., and Morrison, H.: Aerosol indirect effects in a multi-scale aerosol-climate model PNNL-MMF, Atmos. Chem. Phys., 11, 5431-5455, doi:10.5194/acp-11-5431-2011, 2011

Wiedinmyer, C., Quayle, B., Geron, C., Belote, A., McKenzie, D., Zhang, X. Y., O'Neill, S., and Wynne, K. K.: Estimating emissions from fires in North America for air quality modeling, Atmos. Environ., 40, 3419-3432, doi:10.1016/j.atmosenv.2006.02.010, 2006.

Wiedinmyer, C., Akagi, S. K., Yokelson, R. J., Emmons, L. K., AlSaadi, J. A., Orlando, J. J., and Soja, A. J.: The Fire INventory 
from NCAR (FINN): a high resolution global model to estimate the emissions from open burning, Geosci. Model Dev., 4, 625641, doi:10.5194/gmd-4-625-2011, 2011.

Xie, Y. N., Ding, A. J., Nie, W., Mao, H. T., Qi, X. M., Huang, X., Xu, Z., Kerminen, V. M., Petaja, T., Chi, X. G., Virkkula, A., Boy, M., Xue, L. K., Guo, J., Sun, J. N., Yang, X. Q., Kulmala, M., and Fu, C. B.: Enhanced sulfate formation by nitrogen dioxide: Implications from in situ observations at the SORPES station, J. Geophys. Res.-Atmos., 120, 12679-12694, doi:10.1002/2015JD023607, 2015.

Yan, X. Y., Ohara, T., and Akimoto, H.: Bottom-up estimate of biomass burning in mainland China, Atmos. Environ., 40, 52625273, doi:10.1016/j.atmosenv.2006.04.040, 2006.

Yang, S. J., He, H. P., Lu, S. L., Chen, D., and Zhu, J. X.: Quantification of crop residue burning in the field and its influence on ambient air quality in Suqian, China, Atmos. Environ., 42, 19611969, doi:10.1016/j.atmosenv.2007.12.007, 2008.

Zaveri, R. A. and Peters, L. K.: A new lumped structure photochemical mechanism for large-scale applications, J. Geophys. Res.Atmos., 104, 30387-30415, 1999.
Zaveri, R. A., Easter, R. C., Fast, J. D., and Peters, L. K.: Model for simulating aerosol interactions and chemistry (MOSAIC), J. Geophys. Res.-Atmos., 113, D13204, doi:10.1029/2007JD008782, 2008.

Zhang, Y., Fu, R., Yu, H., Qian, Y., Dickinson, R., Silva Dias, M. A. F., da Silva Dias, P. L., and Fernandes, K.: Impact of biomass burning aerosol on the monsoon circulation transition over Amazonia, Geophys. Res. Lett., 36, L10814, doi:10.1029/2009GL037180, 2009.

Zhao, C., Leung, L. R., Easter, R., Hand, J., and Avise, J.: Characterization of speciated aerosol direct radiative forcing over California, J. Geophys. Res.-Atmos., 118, 2372-2388, 10.1029/2012JD018364, 2013.

Zhao, T. and Yatagai, A.: Evaluation of TRMM 3B42 product using a new gauge - analysis of daily precipitation over China, Int. J. Climatol. 34, 2749-2762, 2014. 